\title{
A Broader View of Musical Exoticism
}

\author{
RALPH P. LOCKE
}

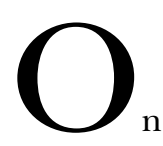

of opera is Dalila in Saint-Saëns's Samson et Dalila (1875). Yet the two love songs with which she brings Samson low-"Printemps qui commence" and "Mon coeur s'ouvre à ta voix"-are not exotic in style. Rather, they involve standard Romantic-era techniques for conveying beauty, passion, and seductiveness. These techniques include ecstatic vocal leaps, melodic phrases that extend asymmetrically, rich harmony, liquid writing for winds, and (in "Mon coeur") the evocation of gentle breezes. The music thereby renders the libretto's portrayal of this beckoning, duplicitous female dramatically specific-and also aesthetically gratifying, which keeps us listening, caring about what Dalila thinks, feels, and does. Furthermore, the opera as a whole-with its systematic

\footnotetext{
Portions of the present article were first presented (under a somewhat different title) to the New York State-St. Lawrence Chapter of the American Musicological Society (April 8-9, 2006), the national meeting of the same Society (November $2-5$, 2006), and the International Musicological Society (July 10-15, 2007). I am grateful to the following, who helped me clarify my thinking, pointed me to crucial materials, and/or shared their own unpublished work: Naomi André, Tekla Babelak, Daniel Beaumont, Jonathan Bellman, Hanita Blair, Olivia Bloechl, Francesca Brittan, Bruce Alan Brown, Carlo Caballero, Catherine Cole, Melina Esse, Roger Freitas, Helen Greenwald, Arthur Groos, Lydia Hammesley, Ellen Harris, Rebecca Harris-Warrick, Kii-Ming Lo, Shay Loya, Patrick Macey, Jürgen Maehder, François de Médicis, Stephen C. Meyer, Christopher Moore, Michaela Niccolai, James Parakilas, Michael Pisani, Jennifer Ronyak, David Rosen, Emanuele Senici, Mary Ann Smart, Marilynn J. Smiley, Jürgen Thym, Holly Watkins, Gretchen Wheelock, Amanda Eubanks Winkler, and Lesley A. Wright.
}

The Journal of Musicology, Vol. 24, Issue 4, pp. 477-521, ISSN 0277-9269, electronic ISSN $1533^{-8} 347$. (C) 2007 by the Regents of the University of California. All rights reserved. Please direct all requests for permission to photocopy or reproduce article content through the University of California Press's Rights and Permissions website, http://www.ucpressjournals.com/reprintInfo.asp. DOI: 10.1525/ jm.2007.24.4.477. 
THE JOURNAL OF MUSICOLOGY

opposition of good and evil, Judaeo-Christian tradition and its Eastern enemies-ensures that we understand Dalila's wiles as typical of women from her region. ${ }^{1}$

Scholars and critics describing how exoticism functions in Samson et Dalila have largely ignored these and other remarkable moments of exotic musical portrayal in the work. Instead, they have focused on the few numbers that are frankly exotic in style. Most often discussed is the big ballet in the last act, the Bacchanale of the Philistines, whose pounding syncopated rhythms and obsessive augmented seconds allude to the Arab music that Saint-Saëns grew to know during winter vacations in North Africa. ${ }^{2}$

The blinkered scholarly response to this thoroughly exoticist opera is typical more generally. Musical exoticism has long been defined in a narrow way: as the incorporation of foreign (or at least strange-sounding) style elements. The present article urges, instead, that musical exoticism be defined broadly, as the process by which exotic places and peoples are represented in musical works. It begins by looking at definitions of musical exoticism from several important scholars with different interests and backgrounds (Thomas Betzwieser, Jonathan Bellman, Jean-Pierre Bartoli), and then contrasting those with a definition of my own that is more comprehensive and more adequate to the wide range of exotic portrayals per musica.

For polemical and practical purposes, the approach (for studying musical exoticism) that one normally encounters in the scholarly and critical literature is here called the "Exotic Style Only" Paradigm, and the proposed new approach is called (not quite elegantly, I admit) the "All the Music in Full Context" Paradigm. The new, broader paradigm contains the prevailing one and much more besides. ${ }^{3}$ Although the

1 Ralph P. Locke, "Constructing the Oriental 'Other': Saint-Saëns's Samson et Dalila," Cambridge Opera Journal 3 (1991): 276-79, 289-98. We first encounter Dalila in the context of-more or less at the head of-the dancing and singing priestesses of Dagon, who "provoke" (according to the stage directions) the Hebrew men (266-67). One feature of "Mon coeur" may carry a vague whiff of exoticness: the descending chromatic motion at the first occurrence of the words "Ah, réponds ... verse-moi!" Or does the chromaticism rather suggest snake-like slitheriness, as a character trait independent of place or ethnicity? On differentiating exotic from non-exotic (but character-defining) style, see nn. 3 and 29 .

2 On hijāz mode in this Bacchanale, see Locke, "Constructing," 266-68. Cf. Myriam Ladjili, "La musique arabe chez les compositeurs français du xixe siècle saisis d'exotisme (1844-1914)," International Review of the Aesthetics and Sociology of Music 26 (1995): 23-26; and Jean-Pierre Bartoli, "L'orientalisme dans la musique française du XIXe siècle: la ponctuation, la seconde augmentée et l'apparition de la modalité dans les procédures exotiques," Revue belge de musicologie $5^{1}$ (1997): 151-53, 161.

3 I stress that I define the new paradigm ("All the Music ...") as incorporating the prevailing ("Exotic Style Only") one. Were I to propose the new paradigm as a nonoverlapping alternative or complement (say: "Non-Exotic Style Only"), I would create the 
"Exotic Style Only" Paradigm remains immensely valuable, especially for many instrumental works, it cannot fully cope with an extended programmatic instrumental work (as we shall briefly see below, with regard to Rimsky-Korsakov's Sheherazade).

Nor can the "Exotic Style Only" Paradigm deal well (as we have briefly seen) with many dramatic works of exoticist intent. The present article concludes by looking at significant excerpts from four such works: a dramatic oratorio by Handel and one opera apiece by Rameau, Bizet, and Puccini. More specifically, it looks at certain passages from each work that portray an exotic people, individual, or situation. Yet because these passages do not employ exotic-sounding music (indeed, no passage in the Handel oratorio does), they have been neglected in the literature on musical exoticism, and the implications of their exotic portrayal have gone largely unexplored.

\section{Exoticism with and without Exotic Style}

The word "exoticism" relates, etymologically, to places or settings "away from" some vantage point considered normative, most often that of the observer him- or herself. Like so many "-isms" (idealism, Romanticism), exoticism can be broadly encompassing and relatively abstract: an ideology, a diverse collection of attitudes and prejudices, an intellectual tendency.

Or it can be broad yet concrete: a cultural trend with rich and varied manifestations. In literature and the visual arts, for example, exoticism is generally sought and found in a work's subject matter and in the evident attitudes and aesthetic aims of the work's creator-but not necessarily in his or her style. Art historians, for example, note that early to mid nineteenth-century French Orientalist paintings rely primarily on standard up-to-date Western techniques, such as the modeling of threedimensional form through perspective, color, and shadow. Delacroix painted hundreds of Middle Eastern scenes yet found the art of the region flat and uninvolving.4 (Non-Western techniques would prove

problem of policing the boundary between exotic and non-exotic style. I believe that such policing is pointless. Exoticness most often depends not just on the musical notes but also on their context or framing (as discussed in the present article-see, for example, note 29) and on other factors as well, notably the nature of a given performance and the musical and cultural preparation of a given listener. On the latter (a listener's associations with certain noises, bits of music, etc.), see my "L'impossible possibilité de l'exotisme musical," trans. Vincent Giroud, in Musique, esthétique et société en France au XIXe siècle: Liber amicorum Joël-Marie Fauquet, ed. Damien Colas, Florence Gétreau, and Malou Haine (Liège: Mardaga, 2007), 91-107.

4 Donald A. Rosenthal, Orientalism: The Near East in French Painting I80o-I880 (Rochester, NY: Memorial Art Gallery of the Univ. of Rochester, 1982), 33 (Delacroix, diary entry of 11 March $185^{\circ}$, on Mughal portraits).

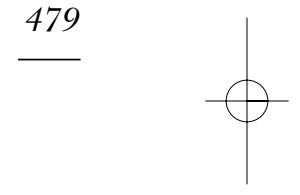


THE JOURNAL OF MUSICOLOGY

more appealing to artists of subsequent generations, including Manet, Gauguin, Picasso, and Matisse.) 5

Within the musical realm, by contrast, exoticism has been treated less as a broad mindset or artistic approach and more as a lexicon of specific stylistic devices that the composer-and presumably many of his or her listeners-associated, rightly or wrongly, with the distant country or people in question. We sometimes even use the word in the plural, saying that a piece makes much or little use of various "exoticisms" typical of the era. ${ }^{6}$ "Exoticisms," in this sense, are small-scale and countable. 7 Or the word can sometimes refer to an exotic style-dialect (comprising a number of those small-scale features). A recent scholar calls the alla turca style-familiar from such works as Mozart's "Rondo alla turca" (the finale of the Piano Sonata in A major, K331) - "the first recognizable exoticism in [Western] music." 8 This phrase may give the erroneous impression, however inadvertently, that before around $175^{\circ}$ exoticist conceptions of distant and different places and peoples left no mark on musical works of the day.

I do not belittle the quasi-empirical hunting for specific devices and coherent dialects of exotic style. Quite the contrary, I would like to start by drawing attention to this approach (and to the lexicons of devices and dialects that it tends to compile) and to dub it the "Exotic Style Only" Paradigm (or, for short, Exotic-Style Paradigm). 9

5 Scholars of visual art focus primarily on iconography (subject matter), such as wall tiles and facial features, and regularly accept that the basic style features (e.g. perspective, brushstroke) are often-especially in the early and mid 19th century, as just notedthose currently prevailing in Western art. See discussion in Jean Alazard, L'Orient et la peinture française au xix é siècle, d'Eugéne Delacroix à Auguste Renoir (Paris: Plon, 1930); Philippe Jullian, The Orientalists: European Painters of Eastern Scenes, trans. Helga and Dinah Harrison (Oxford: Phaidon, 1977); Rosenthal, Orientalism; The Orientalists: Delacroix to Matisse, The Allure of North Africa and the Near East, ed. MaryAnne Stevens (London: Royal Academy of Arts, 1984); James Thompson, The East: Imagined, Experienced, Remembered: Orientalist Nineteenth Century Painting (Dublin: National Gallery of Ireland, 1988); Roger Benjamin, Orientalism: Delacroix to Klee (Sydney: Gallery of New South Wales, 1997); and Locke, "Constructing," 264, 268-69.

${ }^{6}$ There are insightful sections on "satztechnische Exotismen" and "harmonische Exotismen" (precise techniques, in the plural) in Peter Korfmacher, Exotismus in Giacomo Puccinis "Turandot" (Cologne: Verlag Dohr, 1993), 106-44.

7 "Mannerism" is a somewhat parallel case of an "-ism" with both a broad meaning (in art criticism, say) and a small-scale one ("annoying mannerisms" of speech or gesture).

8 Jeremy Day-O'Connell, Pentatonicism from the Eighteenth Century to Debussy (Rochester: Univ. of Rochester Press, 2007), 49, $4^{8}$ ("musical exoticism saw only a limited practice before $1800 ")$.

9 A close parallel is found in the work of writers who focus on stylistic topoi or "topics" in 18 th- and 19 th-century music. Two of the most comprehensive such writers, though, make little mention of musical exoticism (except for alla turca). See Leonard G. Ratner, Classic Music: Expression, Form, and Style (New York: Schirmer Books, 1980), 21 ; and Raymond Monelle, The Musical Topic: Hunt, Military and Pastoral (Bloomington: Indiana Univ. Press, 2006). A detailed lexicon of exotic stylistic features is given, with selected 
This paradigm is rooted, whether explicitly or implicitly, in definitions of musical exoticism that are narrowly based on style. The best currently circulating definitions, including those in Jonathan Bellman's introduction to the collection The Exotic in Western Music and in Thomas Betzwieser's "Exotismus" article in Die Musik in Geschichte und Gegenwart, take as a given that exoticism resides in an attempt at evokingwhether accurately or not-the local music. For Bellman, exoticism consists of "the borrowing or use of ... characteristic and easily recognized musical gestures from the alien culture." ${ }^{10}$ Betzwieser, in the $M G G$ article, states that "exoticism, as it manifests itself in regard to music, can be observed ... in the use of 'exotic' musical material." 1

These short quotations already suggest a point of disagreement. Must exotic materials come directly or indirectly "from the alien culture," as Bellman states? That is, have they been borrowed? ${ }^{12}$ Or are we talking about " 'exotic' musical material," as Betzwieser states, with the crucial word in scare quotes?

The disagreement is more apparent than real. Elsewhere in his introductory essay, Bellman makes clear that the relationship to any actual music of the country or region in question is, at times, slender or nonexistent.

"Musical exoticism" ... may be defined as the borrowing or use of musical materials that evoke distant locales or alien frames of reference. . . Musical exoticism is a matter of compositional craft, of making the notes do something different from what they usually do. ${ }^{13}$

instances from an extensive and varied repertoire, in Michael V. Pisani, "Exotic Sounds in the Native Land: Portrayals of North American Indians" (Ph.D. diss., Eastman School of Music, Univ. of Rochester, 1996), 90-100 and 116-19. Pisani condenses this lexicon into seven categories in his " 'I'm an Indian Too'," in The Exotic in Western Music, ed. Jonathan Bellman (Boston: Northeastern Univ. Press, 1998), 218-57 and 343- 37 (esp. 229-31). I attempt a more comprehensive list of exotic-style categories (some of which are themselves potentially enormous, e.g. "unusual scales and modes") in my forthcoming book Musical Exoticism: Images and Reflections (Cambridge: Cambridge Univ. Press).

1o Jonathan Bellman, "Introduction," in Bellman, Exotic, x. Cf. Bellman's The style hongrois in the Music of Western Europe (Boston: Northeastern Univ. Press, 1993).

${ }_{11}$ Thomas Betzwieser and Michael Stegemann, "Exotismus," in Die Musik in Geschichte und Gegenwart, 2nd rev. ed., ed. Ludwig Finscher (Kassel: Bärenreiter and Stuttgart: Metzler, 1994- ), vol. 3, cols. 226-43. Cf. Thomas Betzwieser, Exotismus und Türkenoper in der französischen Musik des Ancien Reigime: Studien zu einem ästhetischen Phänomen (Laaber: Laaber-Verlag, 1993).

12 Borrowed or, in the more politicized language of recent cultural criticism, "appropriated." See note 40 below and Georgina Born and David Hesmondhalgh, "Introduction: On Difference, Representation, and Appropriation in Music," in Western Music and Its Others: Difference, Representation, and Appropriation in Music, ed. Born and Hesmondhalgh (Berkeley: Univ. of California Press, 2000), 1-58.

13 Bellman, "Introduction," ix. 
Bellman's wording-“different from what [the notes] usually do"allows that a composer may distort the stylistic norms of his or her own musical tradition (until they sound "different") or may even invent a startling style feature outright.

The music theorist Jean-Pierre Bartoli has recently made this point more emphatically with reference to the language of semiotics:

In the artistic domain, one designates by the word "exoticism" a combination of procedures that evoke cultural and geographical Otherness [altérité] ... [by] use of meaning-units [unités significatives] that seem . . . borrowed from a foreign artistic language. ${ }^{14}$

Bartoli's wording-"meaning-units that seem borrowed"-allows for the possibility that the meaning-units are borrowed, but it does not by any means require that they be so. They may be, again, contorted versions of prevailing practices (within the "home" musical style) or pure inventions.

The Exotic-Style Paradigm often proves enlightening. Especially in purely instrumental works, certain readily identifiable devices-e.g. drones, "primitive" harmonies, unusual modes (various HungarianGypsy scales, distinctive pentatonic options, and so on), and acceptedas-characteristic tunes, rhythms, and instrumental sonorities-make up the essential toolkit with which, for centuries now, many composers have created exotic effects. ${ }^{15}$ Much-studied examples include Mozart's aforementioned "Rondo alla turca" and gamelan-influenced works by Debussy, such as "Pagodes." 16

Procedures amenable to analysis within the Exotic-Style Paradigm occur also in many operas set in some real or half-imagined "Elsewhere." They are frequent in such scene-setting numbers as choruses, ballets, and ceremonial processions, where, for example, the more or

${ }^{14}$ Jean-Pierre Bartoli, "Propositions pour une définition de l'exotisme musical et pour l'application en musique de la notion d'isotopie sémantique," Musurgia 7, no. 2 (2000): 65 .

15 These materials are thus often foreign-sounding in the broadest sense. Mary Hunter sagely points out that exotic pieces often offer not an echo of the materials used (or reportedly used) in the given foreign music but rather a "translation" (her word) of the impression that Westerners had of that music (as will be discussed further below). Mary Hunter, "The Alla Turca Style in the Late Eighteenth Century: Race and Gender in the Symphony and the Seraglio," in Bellman, The Exotic in Western Music, $4^{8-52 .}$

16 On the "Rondo alla turca," see, among many discussions, Matthew Head, Orientalism, Masquerade and Mozart's Turkish Music (London: Royal Musical Association, 2000), 64-66, 117-23. Debussy's gamelan-inspired works are discussed by Mervyn Cooke in " 'The East in the West': Evocations of the Gamelan in Western Music," in Bellman, Exotic in Western Music, esp.26o-62; and Day-O'Connell, Pentatonicism, $15^{8-81}$. 
less authentic Chinese melodies in Puccini's Turandot tend to appear. ${ }^{17}$ One of the ablest early handlers of the technique was Gluck, in several ballets and French operas written for Vienna or (later) for Paris. ${ }^{18}$ Another was, of course, Mozart. In Die Entführung aus dem Serail (1782), Mozart based certain numbers for Osmin and for the chorus on socalled "Turkish" musical style features that he knew would be recognized with delight by, and found humorous by, the "Viennese gentlemen" (his phrase) who would be in the audience. ${ }^{19}$

I propose a much broader view of musical exoticism, one that incorporates the Exotic-Style Paradigm but allows for many other musical passages-ones that do not differ from the prevailing musical language of the day-to be considered as contributing to portrayal of an exotic Other. They do so because they are presented in a plainly exoticizing context, such as-in the case of an opera-plot, sung words, sets, and costumes. $^{20}$

This "All the Music in Full Context" Paradigm (or Full-Context Paradigm, for short) does not take as the defining (necessary-andsufficient) component the borrowing or imitating of local style; indeed, it accepts that an exoticist work need not display stylistic oddity at all. This freedom from stylistic constraints follows logically from my more comprehensive definition:

Musical exoticism is the process of evoking in or through musicwhether the latter is "exotic-sounding" or not-a place, people, or social milieu that is not entirely imaginary and that differs profoundly from the "home" country or culture in attitudes, customs, and morals. More precisely, it is the process of evoking a place (people, social

17 Kii-Ming Lo, Turandot auf der Opernbühne (Frankfurt: Peter Lang, 1996), 325-36, and Michele Girardi, Puccini: His International Art, trans. Laura Basini (Chicago: Univ. of Chicago Press, 2000), $211-17$.

18 Notable are the ballet-pantomime La Cythère assiégée (Vienna, 1762), the opéracomique La rencontre imprévue, ou Les pèlerins de la Mecque (Vienna, 1764), a dance of the slaves in Iphigénie en Aulide (Paris, 1774), and a chorus of Scythian women in Iphigénie en Tauride (Paris, 1779). On Gluck and other mid and late 18th-century practitioners of French and German exotic ballet and opera, see Bruce Alan Brown, Gluck and the French Theatre in Vienna (Oxford: Clarendon Press, 1991), 90, 168-71, 186-89, 236-44, and Plate 6; Betzwieser, Exotismus, 118-266; and Anke Schmitt, Der Exotismus in der deutschen Oper zwischen Mozart und Spohr (Hamburg: Verlag der Musikalienhandlung K. D. Wagner, 1988), esp. 13-15.

19 Letter from Mozart to his father, September 26, 1781 , cited in Thomas Bauman, W. A. Mozart: Die Entführung aus dem Serail (Cambridge: Cambridge Univ. Press, 1987), 65.

2o The broader paradigm herein proposed is modeled in part on studies of the interacting elements in opera (e.g. the "multivalent" approach advocated in various ways by Pierluigi Petrobelli, Harold Powers, James Webster, Carolyn Abbate, and Roger Parker), in German Lieder (as explored by, notably, Ann Clark Fehn, Rufus Hallmark, and Jürgen Thym), and in film, music video, and advertising (respectively, Claudia Gorbman, Carol Vernallis, and Nicholas Cook). 


\section{THE JOURNAL OF MUSICOLOGY}

milieu) that is perceived as different from home by the people making and receiving the exoticist cultural product. ${ }^{21}$

The place, I should add, differs from home in outward aspect. Under the surface, as we shall see, the exotic locale may be perceived as, in some ways, familiar.

I do not disparage the "Exotic Style Only" Paradigm-the one that follows from such definitions as those of Bellman, Betzwieser, and Bartoli. Quite the contrary, I eagerly incorporate it into the "All the Music in Full Context" Paradigm as one set of options. I even note, with some disgruntlement, that important discoveries made within the confines of the Exotic-Style Paradigm and aired in specialist scholarly studies have not yet found their way into the more general music-historical literature (such as encyclopedias and broad survey books). Examples include certain observations by Miriam Whaples and Thomas Betzwieser about specific types of "exotic" marches (and certain recurring "Turkish" and "Janissary" tunes) in the 17 th and 18 th centuries, and Donald Mitchell's argument that Mahler's use of heterophony in Das Lied von der Erde may derive from some familiarity with Guido Adler's descriptions of heterophonic techniques in Chinese and other non-European musics. ${ }^{22}$ Furthermore, new studies consistent with the Exotic-Style Paradigm are reaching publication all the time, though often, again, for a relatively limited readership. ${ }^{23}$

21 This current, expanded definition derives from one that I first proposed in the "Exoticism" entry in New Grove Dictionary of Music and Musicians, 2nd ed. (New York: Grove's Dictionaries, 2000), and in my article "Exoticism and Orientalism in Music: Problems for the Worldly Critic," in Edward Said and the Work of the Critic: Speaking Truth to Power, ed. Paul A. Bové (Durham: Duke Univ. Press, 2000), 257-81, 3o6-12.

${ }^{22}$ Miriam K. Whaples, "Early Exoticism Revisited," in Bellman, The Exotic in Western Music, 19-2 1, and Thomas Betzwieser, Exotismus und Türkenoper in der französischen Musik des Ancien Reigime: Studien zu einem ästhetischen Phänomen (Laaber: Laaber-Verlag, 1993), 102-9. Donald Mitchell, Gustav Mahler, Songs and Symphonies of Life and Death: Interpretations and Annotations (Berkeley: Univ. of California Press, 1986), 62-64, 125-27, 451, $3^{8} 9^{-}-9^{2}, 624-34$.

${ }_{23}$ Hervé Lacombe, The Keys to French Opera in the Nineteenth Century, trans. Edward Schneider (Berkeley: Univ. of California Press, 2001), 1 79-205; Nasser Al-Taee, "Fidelity, Violence, and Fanaticism: Orientalism in Wranitzky's Oberon, König der Elfen," Opera Quarterly 17, no. 1 (2001): 43-69; Michael V. Pisani, Imagining Native America in Music (New Haven: Yale Univ. Press, 2005); David Pacun, "'Thus We Cultivate Our Own World, and Thus We Share It with Others': Kósçak Yamada's Visit to the United States in 19181919," American Music 24 (2006): 67-91, esp. 9o, 93 (on harmonization of Japanese modes); Ralph P. Locke, "Spanish Local Color in Bizet and Verdi: Unexplored Borrowings and Transformations," in Stage Music and Cultural Transfer: Paris, I830-I9I4, ed. Annegret Fauser and Mark Everist (Chicago: Univ. of Chicago Press, forthcoming); and Shay Loya, "Beyond Gypsy Stereotypes: Harmony and Structure in the Verbunkos Idiom," forthcoming in Journal of Musicological Research. 
I do not mean to imply, because of the names that I have given the two paradigms, that the narrower one (Exotic-Style) inherently excludes consideration of "context." Certain studies of exotic-style works and passages have taken the important step of bringing non-musical elements, and also historical-cultural contexts, prominently into discussion. (For reasons of space, these studies cannot be discussed here.) ${ }^{24}$ Still, the primary trend among scholars and critics using the Exotic-Style Paradigm has been to treat style traits as relatively self-contained "markers" of Otherness and to give limited consideration, if any, to how the composer's and listener's perception of style was or is affected by factors outside the notes. This tendency echoes certain broadly formalistic trends within mid and late 2oth-century musicology as a whole (notably an emphasis on "the music itself") — trends that, in turn, bear comparison to such roughly contemporary trends in the study of literature as "New Criticism." ${ }_{5}$

24 Thoughtful critics have recently explored the aesthetic merits and cultural function ("cultural work") of compositions that "borrow" (or "appropriate" or "are influenced by") musics of other groups or cultures. See Born and Hesmondhalgh, "Introduction"; Jonathan Bellman, "The 'Noble Pathways of the National': Romantic and Modern Reactions to National Music" The Pendragon Review 1, no. 2 (Fall 2001): 45-65; Derek B. Scott, "Orientalism and Musical Style," in From the Erotic to the Demonic: On Critical Musicology (Oxford: Oxford Univ. Press, 2003), 155-78, 235-39; and Matthew Head, "Musicology on Safari: Orientalism and the Spectre of Postcolonial Theory," Music Analysis 22 (2003): 211-30. Two studies of specific repertories are Pisani, Imagining Native America in Music, and Shay Loya, "The Verbunkos Idiom in Liszt's Music of the Future: Historical Issues of Reception and New Cultural and Analytical Perspectives" (Ph.D. diss., King's College, London, 2006), 111-40. Pisani's book offers extensive information on attitudes and historical circumstances that shaped the composition and reception of the "Indian"portraying musical works discussed, including parlor songs and film scores. Loya wrestles with the very terminology that uncritically equates genre with ethnicity and that catalogues whole pieces accordingly (hence his usage of "verbunkos idiom" rather than "Gypsy style" or "Hungarian work"). At the same time, he discusses the stereotypical overtones of "Gypsiness" in Liszt's day and even today ("The Verbunkos Idiom," 23-29). The population known to outsiders as Gypsies (Zigeuner, etc.) more often call themselves Roma and are now rightly so described by social scientists and ethnomusicologists.

${ }_{25}$ On the contrast between a (primarily) notes-only musicology-with its frequent claims to a quasi-scientific empiricism and its leanings toward modernist "cleanness"and a more fully contextual (and perhaps necessarily messier) one, see Joseph Kerman, Contemplating Music: Challenges to Musicology (Cambridge: Harvard Univ. Press, 1985), 113-81 (including remarks on New Criticism, and on the "positivist" tendency to exclude context); Richard Crawford, American Studies and American Musicology: A Point of View and a Case in Point (Brooklyn: Institute for Studies in American Music, 1975), 14; Ralph P. Locke, "Musicology and/as Social Concern: Imagining the Relevant Musicologist," in Rethinking Music, ed. Nicholas Cook and Mark Everist (Oxford: Oxford Univ. Press, 1999), 499-530 (esp. 502-10); Ralph P. Locke, "Response by Ralph P. Locke," in Musicology and Sister Disciplines: Past, Present, Future: Proceedings of the I 6th International Congress of the International Musicological Society, London, I997, ed. David Greer, Ian Rumbold, and Jonathan King (London: Oxford Univ. Press, 2000), 209-1 7 (dealing with aesthetic aspects of concertgoing and other sociological phenomena in music); and Richard Taruskin, "Speed Bumps" [review of the Cambridge History of Nineteenth-Century Music and the Cambridge History of Twentieth-Century Music], I 9 th-Century Music 29 (2005-6): 185-295. 
THE JOURNAL OF MUSICOLOGY

\section{The Special Case of Programmatic Instrumental Works}

I have stressed that the Exotic-Style Paradigm is particularly well suited to instrumental works of frankly exotic intent. But it proves inadequate when such a work is not written entirely in exotic style. An interesting case is Rimsky-Korsakov's symphonic suite Sheherazade. One might at first think of Sheherazade as exotic through and through. After all, it is frankly based on tales from the Thousand and One Nights (or Arabian Nights). ${ }^{26}$ It also employs various stylistic devices that were recognizable markers of Middle Easternness at the time (and, for many listeners, remain so today). In particular, the recurring violin solowhich, by all accounts, represents Sheherazade herself-begins with a memorable stepwise-descending minor-mode melody, in which each main note alternates with its upper neighbor in triplets (e.g., $\hat{5} \hat{4}-\hat{5}-\hat{4}$ $\hat{3}-\hat{4}-\hat{3} \hat{2}-\hat{3}-\hat{2} \hat{1})$, resulting in the very kind of decorative, curvaceous line that in writings about this and other works was (and still is) often described as "arabesque." ${ }^{27}$ (One current program note, echoing certain descriptions of women in the Nights, calls this melody for the female protagonist "willowy.") 28

But a look at the score of Sheherazade quickly reveals passages that are not marked musically as Middle Eastern. These passages, too, help to retell certain Arab legends and sketch certain scenes deemed "typical" of the region: Sinbad's ship roving the sea, a tender episode between a young prince and princess, and the bustling activity at an outdoor market. We know that the recurring theme that opens the piece (in

${ }_{26}$ In the score, Rimsky-Korsakov himself provided a paragraph-long program and movement titles. He later distanced himself from these (though to little avail). Nikolai Rimsky-Korsakov, My Musical Life, trans. Judah A. Joffe from the fifth Russian edition (New York: Alfred A. Knopf, 1942), 292-24.

${ }_{27}$ "Arabesque" is a standard Western term for a curvaceous line or shape in Middle Eastern visual art. In Western art music, correspondingly, it often refers to a curvaceous melody or countermelody that is particularly supple and decorative. In addition, it also can mean-for German writers on aesthetics, for Schumann, often for Debussy-an artistic manifestation of pure, purposeless delight. See such varied writings as Franz Liszt, Des Bohémiens et de leur musique en Hongrie, rev. ed. (Leipzig: Breitkopf \& Härtel, 1881), 403; W. J. Henderson, "A Note on Floridity," Musical Quarterly 2 (1916): 348; Françoise Gervais, "La notion de l'arabesque chez Debussy," Revue musicale 241 (1958): 3-23; JeanJacques Eigeldinger, "Debussy et l'idée d'arabesque musicale," Cahiers Debussy 12-13 (1988-89): 5-14; Caroline Potter, "Debussy and Nature," in The Cambridge Companion to Debussy, ed. Simon Trezise (Cambridge: Cambridge Univ. Press, 2003), 34-35, 143-47, 15 $5^{8-61}, 183$, 253; and Gurminder Kaur Bhogal, Arabesque and Metric Dissonance in the Music of Maurice Ravel (I9O5-I9I4) (Ph.D. diss., Univ. of Chicago, 2004), 34-1 14, 188-259.

${ }_{28}$ Note by the musicologist and professional annotator Paul J. Horsley, written for the Philadelphia Orchestra, at http://www.carnegiehall.org/textSite/box_office/events/ evt_6614.html (accessed 24 August 2007). Cf. various descriptions in the Thousand and One Nights, such as "like a willow bough or a stalk of sweet basil, her beauty struck the eye and bewildered the mind"- "The Third Dervish's Tale," in The Arabian Nights, vol. 1, ed. Muhsin Mahdi, trans. Husain Haddawy (New York: Norton, 1990), 127. 
unharmonized unisons) represents Sultan Shahriar thanks to the composer's plot summary published at the head of the score and because the theme is stern and threatening, though not notably exotic in style. ${ }^{29}$

Likewise, in the work's second seascape-the section of movement 4 in which "the Ship Breaks against a Cliff That Is Surmounted by a Bronze Horseman"-the rising sequences, rapid scales upward and down, and unsettled harmonies are much like those used in musical sea-storms that occur in other climes (e.g. along the Norwegian coast in Wagner's Der fliegende Holländer). $3^{\circ}$ Yet concert-hall audiences and CD listeners perceive Rimsky-Korsakov's brief but violent sea scene as part of an exotic narrative, i.e. as one in a string of Arabian Nights tales. ${ }^{31}$ They do so because they hear it in the context of the composer's plot summary, the colorful titles of the four movements, and the many sections of the work that do sound "Middle Eastern."

\section{Exoticism in Musicodramatic Works}

But it is operas and other dramatic works that demand-or, put another way, that reveal most fully the interpretive power of-the "All the Music in Full Context" Paradigm. Musicodramatic works operate very differently than do purely instrumental pieces. In dramatic oratorios, the music is heard within the frame of plot and sung words. In opera, the music is heard against an even more extensive array of nonmusical elements: plot and sung words, again, as well as costumes, sets, stage

29 Some might argue that the sultan's theme is not entirely normative, given that it outlines a descending whole-tone fragment. Furthermore, its statement in bare unison might be construed as reflecting the well known "lack of harmony" in non-European music. To these objections, one might reply that whole-tone fragments were becoming a normative option in self-consciously advanced musical style (in Liszt as well as in much Russian music) and that stentorian unharmonized openings had been used non-exotically by many previous composers (e.g. Haydn, Symphony no. 104; Beethoven, Symphony No. 5; Liszt, Piano Concerto No. 1).

$3^{\circ}$ The episode in question occurs near the beginning of the Tale of the Third Dervish. The Black Mountain is magnetic; it thus draws the nails out of the planks of any ship that comes near, causing the ship to fall apart. Atop the mountain stands a bronze horse and rider. On the composition, dissemination, publication history, and elaborate narrative technique of the Nights, see Robert Irwin, The Arabian Nights: A Companion (London: Allen Lane, 1994), and Daniel Beaumont, Slave of Desire: Sex, Love, and Death in the Ioo I Nights (Madison, NJ: Fairleigh Dickinson Press, 2002), $15^{-31}$.

${ }^{31}$ Rimsky-Korsakov's sea even becomes calm again (mvt. 4, mm. 629-40, Poco più tranquillo, beginning with pianissimo arpeggios in the clarinet), as does the sea in the Third Dervish's story after the protagonist, fulfilling the instructions of a voice he hears in a dream, topples the bronze warrior and buries the bronze horse. This second seascape in Sheherazade is a developmental variant of the one in mvt. 1, and both use a theme that derives plainly from the unison "Sultan" theme. Further, see Nasser Al-Taee, "Under the Spell of Magic: The Oriental Tale in Rimsky-Korsakov's Scheherazade," in Arabian Nights, ed. Saree Makdisi and Felicity Nussbaum (Toronto: Univ. of Toronto Press, forthcoming). 
movement, and dance. Despite the resulting wide range of representational possibilities in musicodramatic works, however, existing studies of exotic operas and oratorios tend to focus on those few scenes or passages that strike listeners as sounding non-Western and that thereby fit the "Exotic Style Only" Paradigm.

In Madama Butterfly, for example, scholars have identified many passages that make use of pentatonic modes or even of entire Japanese tunes (which Puccini had gathered for the purpose from books and other sources)..$^{2}$ By contrast, scholars have tended to overlook numerous passages in that work that-though making no use of pentatonic mode, distinctive instrumental sounds, or any other devices that could be taken as markers of Japan-nonetheless help portray certain features of "the Japanese," such as Cio-Cio-San's delicacy, credulity, and submissiveness.33

A more drastic result of the dominant Exotic-Style Paradigm is that studies of exoticism in opera and other dramatic genres-notably those of Whaples, Betzwieser, and Timothy D. Taylor-have tended to leave unmentioned the many Baroque-era operas and dramatic oratorios that focus on a despicable Eastern tyrant (or have explicitly excluded those works at the outset), simply because they rarely if ever invoke exotic styles.34 One prominent Baroque-opera scholar (Silke Leopold)

$3^{2}$ Girardi, Puccini, 21 1-1 7; cf. Arthur Groos, "Cio-Cio-San and Sadayakko: Japanese Music-Theater in 'Madama Butterfly,'” Monumenta Nipponica 54 (1999): 41-73.

33 Three brief exceptions, involving the perceived smallness of "the Japanese," are Mosco Carner, Puccini: A Critical Biography, 2nd ed. (London: Duckworth, 1974), 385 ("diminutive people and things"), 391 ("tiny tripping feet"; "that 'quaint', fussy, doll-like world"); Kimiyo Powils-Okano, Puccinis "Madama Butterfly" (Bonn: Verlag für systematische Musikwissenschaft, 1986), 89; and Susan McClary's discussion of "diminutive twittering," in her "Mounting Butterflies," in Jonathan Wisenthal, Sherrill Grace, Melinda Boyd, Brian McIlroy, and Vera Micznik, eds., A Vision of the Orient: Texts, Intertexts, and Contexts of Madame Butterfly (Toronto: Univ. of Toronto Press, 2006), 24-25.

34 Whaples, in her dissertation, had set out (as she later put it) to "investigate the influence ... of descriptions and quotations of all non-European musics in the available travel literature on composers of exotic stage works before 1800" "Early Exoticism Revisited," 4). Betzwieser's definition in MGG allows only three conditions that might permit a work to be considered exotic: if it uses native instruments (or presumably ones similar to them or standing for them); if it uses native music (or music odd enough to be understood as standing for it); or if it stages various foreign "rites" ("Exotismus," cols. 226-27). The same entrance criteria guide the selection of works discussed in his important book Exotismus (as he indicates on 16-17). My definition, by contrast, allows a work to be described as substantively exotic in intent and effect if the foreign characters, their customs, and the actions of this or that individual are portrayed in ways that differ notably from the ways in which Westerners are most often-I am not saying always-portrayed in the same genre. In a sense, I am expanding Betzwieser's third category (foreign ceremonies or rituals) to include all of human life, activity, and behavior in the portrayed location. Most recently Timothy D. Taylor explains that he omits Handel operas and oratorios from discussion because they do not rely upon "musical signs signifying nonwestern Others." Taylor, Beyond Exoticism: Western Music and the World (Durham: Duke Univ. Press, 2007), 10. 
frankly states that "it is not until the second half of the eighteenth century that operatic plots from the Islamic cultural region find significant [grösseres] interest.... Metastasio treats no Islamic subject matter." 35 Such a brief formulation gives, no doubt inadvertently, the erroneous impression that few if any important works from before $175^{\circ}$ were situated in "the Islamic cultural region." Yet two of Handel's notable successes, Rinaldo and Tamerlano-1711 and 1724, respectively-take place in, respectively, Ottoman-controlled Palestine (near Jerusalem) and Mongol-controlled Byzantium, and several major characters in both works are Muslim. ${ }^{6}$

Another opera scholar (Gilles de Van) pushes the date of onset even later, stating that "the great age of exoticism in the operatic domain" began in the early 19th century, when locations became more geographically specific through theatrical and musical couleur locale and when the characters were as a result "marked by their place of origin." 37 That last phrase gives the unfortunate impression that in 17 th- and 18 th-century operas and dramatic oratorios, non-Europeans were not presented and characterized as in any way different-neither the numerous Eastern monarchs (kings and queens of Babylonia, Persia, and India), nor the occasional but prominent East Asian courtiers (as in Metastasio's important libretto L'eroe cinese, 1752)..$^{8}$ Native leaders

35 Silke Leopold, "Zur Szenographie der Türkenoper," Analecta musicologica 21 (1982): 371 .

${ }^{6}{ }^{6}$ Rinaldo is, in part, a "sorceress" opera, based on the struggle between Christian knights and nefarious Muslims who have supernatural powers; Alcina (1735) and the more rarely performed Orlando (1733) are further examples by Handel.

37 Gilles de Van, "L'exotisme fin de siècle et le sens du lointain," in Letteratura, musica e teatro al tempo di Ruggero Leoncavallo: Atti del 20 Convegno internazionale "Ruggero Leoncavallo nel suo tempo," ed. Lorenza Guiot and Jürgen Maehder (Milan: Casa Musicale Sonzogno, 1995), 103, 105 .

$3^{8}$ On Metastasio's oft-set drama of Alexander and the wildly emotional king of India (Porus), see the end of the present article. Kii-Ming Lo, even more explicitly than de Van, rules out all early operas set in the ancient Middle East as constituting portrayals of non-Europeans: "Die Präsenz außereuropäischer Länder in der europäischen Operngeschichte beginnt mit der Darstellung der Entdeckung und Conquista Lateinamerikas." The first such example that Lo therefore considers relevant (even though there had been many previous operas involving Turks, ancient Persians, and so on) is the 1690 Roman opera Il Colombo by Bernardo Pasquini, to a libretto by Cardinal Pietro Ottoboni. See "China-Mythen im italienischen Opernlibretto des Settecento," in Peter Csobádi, Gernot Gruber, Jürgen Kühnel, Ulrich Müller, Oswald Panagl, and Franz Viktor Spechtler, eds., Politische Mythen und nationale Identitäten im (Musik-)Theater: Vorträge und Gespräche des Salzburger Symposions 20о I (Anif/Salzburg: Verlag Mueller-Speiser, 2003), 1:185. L'eroe cinese was much imitated in opera libretti over the next few generations, as Lo has demonstrated, and Gluck set Metastasio's other Chinese libretto-Le cinesi-enchantingly in 1753, using an expanded version prepared by Metastasio himself. See "China-Mythen," 186-91. Lo goes on to argue that "von Exotismus oder einer Chino[i]serie des 18. Jahrhunderts kann ... weder in L'eroe cinese noch in Le cinesi die Rede sein" (190). Surely, though, the Chinese setting affected the ways that audiences of the day responded to the 


\section{THE JOURNAL OF MUSICOLOGY}

of New World peoples (notably Montezuma, a central character in operas by such prominent composers as Purcell, Vivaldi, and Graun) also frequently appear in dramatic works. 39

To be sure, something very different and special does begin to occur after around $175^{\circ}$, first with the spread of the alla turca style, and then, in the course of the 19th century, with the ever-increasing awareness of Scottish music, Hungarian-Gypsy music, and the musical traditions of regions yet more distant, including India, China, Southeast Asia, Japan, sub-Saharan Africa, and North America (especially its African-American and its Native-American strands). Exoticism thus begins to overlap with a distinct process that would become increasingly important in the 2oth century (and beyond), namely musical interchanges between "the West" and "the rest." For such a process of interchange, social scientists have devised various intentionally nonjudgmental (value-free) terms, including "transculturation." ${ }^{\circ}$ I stress

unusual happenings in both works. In L'eroe cinese, for example, a Chinese imperial minister switches the emperor's baby son with his own to allow the former to avoid being killed and to ensure that, in time, the boy would grow to inherit the throne. Such a premise might have been considered implausible if situated among Europeans. (The one famous baby-switcher in 19th-century opera-Azucena in Verdi's Il trovatore, 1853 -is, analogously, not a normative European but a Gypsy.)

39 On operas featuring Montezuma and other leaders or New World peoples, see two studies by Jürgen Maehder: "The Representation of the 'Discovery' [of America] on the Opera Stage," in Carol E. Robertson, ed., Musical Repercussions of 1492: Encounters in Text and Performance (Washington, D.C.: Smithsonian Institution Press, 1992), 257-88; and "Die Opfer der Conquista: Das Volk der Azteken auf der Opernbühne," in Peter Csobádi, Gernot Gruber, Ulrich Müller, et al., eds., "Weine, weine, du armes Volk!": Das verführte und betrogene Volk auf der Bühne, 2 vols. (Anif/Salzburg: Müller-Speiser, 1995), 1:265-87. Late outcroppings are discussed in James Parakilas, "The Soldier and the Exotic: Operatic Variations on a Theme of Racial Encounter," pt. 1, Opera Quarterly 10, no. 2 (1994): 36-38 (on Spontini's Fernand Cortez), and in Francesco Izzo, "Exotism [sic], Colonialism and Oppression in Italian Early Romantic Opera," in Csobádi, et al., "Weine, weine, $" 317-26$.

$4^{\circ}$ Cultural anthropologists (and hence many ethnomusicologists) helpfully explain cultural identity as being fashioned through negotiation and creative appropriation. Particularly relevant for the types of exoticist works discussed in the present article are the concepts of cultural exchange/transfer, hybridity (see n. 41), musical process (vs. musical product), colonial encounter, reciprocity (as proposed by Bronislaw Malinowski), and transculturation (as proposed by Fernando Ortiz, with specific regard to ethnically blended musical practices in Cuba). Shay Loya specifically contrasts the "transculturation model" and the "appropriation" model, preferring the former as being more mutual and nuanced, less politically prescriptive ("The Verbunkos Idiom," 11 1-40). A notable study of "intercultural" composition is Christian Utz, Neue Musik und Interkulturalität, Beihefte zum Archiv für Musikwissenschaft $5^{1}$ (Stuttgart: Franz Steiner, 2002). An exemplary study of (non-musical) cultural exchange is Nancy Bisaha, Creating East and West: Renaissance Humanists and the Ottoman Turks (Philadelphia: Univ. of Pennsylvania Press, 2004). On the distinction between "musical process" and "musical product," see John Blacking, "The Study of Man as Music-Maker," in John Blacking and Joann W. Keali'inohomoku, eds., The Performing Arts: Music and Dance (The Hague: Mouton, 1979), 13, and several other essays in that volume. 
that musical transculturation and musical exoticism overlap but are not identical.41 Exoticism-as the "All the Music in Full Context" Paradigm permits us to see-has often existed in the absence of transcultural influences, and even in the absence of any attempt at making the music sound "strange."

A more comprehensive sense of how music can portray an exotic place, people, or individual has been glimpsed in insightful studies of one or several works. Mary Hunter, for example, has pointed out that the violent and irrational aspects of the (largely invented) alla turca style represent the impression of incoherence that Westerners attributed to Turkish music (rather than representing the sounds of that music themselves) and also symbolize the (perceived) violent and unpredictable behaviors of the region's inhabitants. $4^{2}$ The Full-Context Paradigm happily calls upon such studies and makes explicit their ramifications.

The Full-Context Paradigm is, as I said, especially valuable in theater works and oratorio, where exotic musical codes are only one kind of tool available to a composer seeking to carry out an exoticized scene or drama. A moment's thought should make it obvious that an opera (or dramatic oratorio) set in an exotic locale may engage almost any stylistic and formal resource-musical, verbal, visual, choreographicin order to portray a variety of accepted exotic types. These types include the vicious warlord, his ignorant male followers, the conveyer of ancient Eastern wisdom, the seductive female, as well as-the latter's near-opposite-the sensitive woman who suffers from (what is portrayed as) the ingrained misogyny of the society in question. 43 Similarly, such a work may use a wide range of musical and other materials to construct situations or moods (menacing, deserted, entrancing, mystical, innocently idyllic, and so on) that were understood at the time as characteristic of the place or people. The "All the Music in Full Context"

$4^{1}$ There is an immense literature on present-day musical transculturation or hybridity (moving from the West to the rest, and from metropolitan centers to rural and former colonized areas, but also the reverse), and on the related question of cultural identity through the making and consumption of music. See, for example, Bruno Nettl, The Western Impact on World Music: Change, Adaptation, and Survival (New York: Schirmer Books, 1985); Mark Slobin, Subcultural Sounds: Micromusics of the West (Hanover, NH: Wesleyan Univ. Press, Univ. Press of New England, 1993); Philip Bohlman, The Music of European Nationalism: Cultural Identity and Modern History (Santa Barbara, Cal.: ABC-Clio, 2004); and John Morgan O'Connell, "In the Time of Alaturka: Identifying Difference in Musical Discourse," Ethnomusicology 49 (2005): 177-205.

42 Hunter, "The Alla Turca Style," $50-52$. Hunter draws attention (71-73) to a very different exotic musicodramatic portrayal using (as in the Rameau and Handel cases below) non-exotic-sounding music. In the harem women's trio in Haydn's Lincontro improvviso, she notes, the exquisite sensual, overlapping vocal lines convey the three harem women's sexual yearning and availability.

43 See my "Reflections on Orientalism in Opera and Musical Theater," Opera Quarterly 10 , no. 1 (1993): $4^{8-64}$. 
Paradigm, unlike the currently prevailing one, has the freedom to consider any and all resources that assist in these various portrayals.

How this operates will not surprise scholars who deal with opera or film music (or, indeed, song), since it is simply a special case of the more general ways that music functions in dramatic and other overtly representational and/or narrative genres. 44 The words and visual elements in an opera, oratorio, or film place the character or group in a given Elsewhere. Often, the music marks the character or group indelibly as "barbarous," "seductive," "wise," or whatever. The audience melds the two discrete messages into an indissoluble whole. "This unfamiliar Elsewhere [Japan, North Africa, etc.]," they sense, "is a place of barbarity" (or seduction, wisdom, or other qualities). Music in these dramatic genres thus helps "characterize" (to use a term standard in much criticism of opera and art song), just as it often does when the representation involves madness, supernatural creatures, women, or other conditions, groups, or individuals that have long been viewed as Other, i.e. as departing in some basic way from the heroic, masculine norm.

This much seems reasonable, indeed obvious. I would like to push the argument even further. The music in certain exoticist works or passages may not be closely reflective of the exotic people's quality or characteristics (as defined by the words and dramatic action). Rather, these instances offer good, effective, even (by some lights) great music that registers as compatible with-in other words, it does not conspicuously contradict - the quality or mood defined by those words and actions. The composer puts into gear all the usual ways and means of compositional excellence-melodic and harmonic coherence, subtle variation in phrase structure, orchestration that is delicate or impressive, and so on-to keep us listening, watching, and (as I mentioned at the outset, with regard to Dalila) feeling involved.

An extreme instance might be the melismatic vocal writing in certain 18 th- and early 19th-century works that are set in this or that Elsewhere. If we were to examine such a passage of fioritura in isolation, on the page, we might be tempted to term it a purely musical device and to describe it as a horizontal play of pitches and rhythms, enlivened perhaps by the thrill and risk of live performance but not indicating

44 Although the present article focuses entirely on "high-art" genres, I should point out that exotic portrayals in popular song often avoid using stylistic markers in the music, yet the music there, too, serves as an effective, even delightful vehicle for conveying words that use intensely stereotypical, even noxious ethnic images. Various songs about an individual from a distant land (piccola cinese, petit nègre, and so on) are found in two amazing anthologies of once-beloved recordings from before World War II: Donne di terre lontane, Fonografo italiano 1890-1940, raccolta di vecchie incisioni [italiane] scelte e presentate da Paquito Del Bosco, series V, no. 3 (Cetra CD FC ${ }_{3} 653$, ca. 1995, first released as an LP in 1980); and Chansons coloniales et exotiques [françaises] I9o6-I942 (2 CDs, on the French EPM label: EPM983312/ADE798, 1995). 
anything more specific. We might even have trouble differentiating it, in purely technical terms, from florid passages in certain sonatas for melody instrument and keyboard (or continuo). Within an aria in an opera or dramatic oratorio, though, such singing is more productively regarded as a generic emblem of feeling (and/or of physical movement) that takes on the coloration of the words and dramatic situation into which it is placed. One and the same melismatic passage may tell as vengeful in one context and as desirous or determined in another.45

"Illogical!": such is the usual objection of those who insist that art must consist of a line-up of one-to-one semiotic indicators that need no context to do their work. But audiences regularly experience this kind of "illogical," context-dependent artistic truth in the opera house, concert hall (for oratorio), and movie theater. $4^{6}$

In the remainder of the present article, I would like to show how the "All the Music in Full Context" Paradigm can help illuminate four exoticist works that are strikingly diverse in message and means. In each case, we will pay attention to the words, the dramatic action, and a wide range of musical devices, whether the latter lie within or outside the traditional lexicon of "exotic" musical topoi. We thereby enrich our understanding of how diversely, powerfully, sometimes disturbingly the exoticizing process can function in genres that combine music with dramatic representation. In particular, I will draw attention to instances in which musical elements that are inherently locale-neutral acquire exoticist implications by being placed in the context of exotically

45 A high-energy melisma tends not to be used for a text of tenderness, lament, or despair. In Baroque works-as also in Mozart, and in primo ottocento opera-a general distinction prevails between more-energetic and less-energetic types of melisma.

$4^{6}$ Arthur Schopenhauer, for one, experienced it, and recorded his astute reaction. Coloratura and other highly patterned vocal lines, he argues, can embody the intensity of a feeling rather than its content (which is specified by the words): "The inexhaustibleness of possible melodies corresponds to the inexhaustibleness of nature [as seen] in the variety of individuals, physiognomies, and life patterns [Lebensläufen].... [Yet] music never expresses a given phenomenon but, rather, the inner essence, the in-itself, of any phenomenon.... Words ... should never forsake [their] subordinate position in order to make themselves the chief thing, with the music becoming a mere means of expressing the [words of the] song. ... No one has kept so free from this mistake as Rossini" (Der Wille als Welt und Vorstellung, ed. Wolfgang Frhr. von Lühneysen (Darmstadt: Wissenschaftliche Buchgesellschaft, 1974), vol. 1, 364-65 (in bk. 3, sect. 52). Scholars of Italian opera rarely address this point directly or even seem willing to consider its frank willingness to see music as not closely determined by text. Frits Noske, for example, raises the "Illogical!" objection. The music of a given cabaletta either "radically contradicts" what we know about the character who is singing it (e.g. that he or she is "ingenuous") or else "is ... in accord with [a more extroverted or passionate] character and situation" (The Signifier and the Signified: Studies in the Operas of Mozart and Verdi [The Hague: Martinus Nijhoff, 1977], 276). Noske's view presumes that a naive character never experiences passionate emotion or at least never displays it. But surely vocal display often serves as an emblem of a character's inner feelings (here being shared with us, as if telepathically), whether or not he or she reveals them to other characters in the opera. 


\section{THE JOURNAL OF MUSICOLOGY}

pointed words and drama. (For purely practical reasons, I do not give equal attention to decisions about sets, costumes, stage movement, and dance in the present article.47 Further factors that might be considered include a given performance-or, in opera, a given production-and the different cultural and musical expectations that listeners may bring to an exotic work, or indeed to any work.)

Two of the four examples are from the Baroque era and include extended portrayals of, respectively, a 16 th-century Incan tyrant and an ancient Babylonian one. As I noted earlier, existing studies of musical exoticism-such as those by Whaples, Betzwieser, and Taylorpointedly exclude from consideration the hundreds of examples of tragédie lyrique, opera seria, and other Baroque genres-works by Lully, Handel, and others - that center on, or involve as major characters, Eastern or New World tyrants. The standard rationale for such exclusion is that the music in no way sounds non-European or even simply unusual. $4^{8}$ This hobbles any just appreciation of how the West portrayed the East (and the New World) in important musical genres during those crucial centuries and decades before Mozart. I therefore begin my examples with two clear, if strikingly disparate, instances from the High Baroque.

\section{Rameau's Anticolonialist Agitator}

The Peruvian act or entrée from Rameau's Les Indes galantes is a glaring example. Sylvie Bouissou (editor of the collected edition of Rameau's works) calls the first section of this entrée "weak," unlike the middle section (the Incas' Festival of the Sun, with its several remarkable instrumental movements, two of which have distinctly exotic or at least ancient-"weird" features) and the final one (built around the astonishing orchestral rendition of a volcano erupting).49 But that first

47 On the crucial impact of decisions about locale for the visual side of opera (sets, costumes), see Mercedes Viale Ferrero, " 'Come su ali invisibili': viaggiatori immaginari tra provincie e capitali," in Nazionalismo e cosmopolitismo nell'opera fra '8oo e 'ooo: atti del 3. Convegno internazionale "Ruggero Leoncavallo nel suo tempo": Locarno, Biblioteca cantonale, 6-7 ottobre 1995, ed. Lorenza Guiot, Jürgen Maehder, and Evan Baker (Milan: Sonzogno, 1998), 229-38 (esp. 230-32, on operas with "rustic" and other lower-class settings); Mercedes Viale Ferrero, "Riflessioni sulle scenografie pucciniane," Studi pucciniani 1 (1998): 19-42; Leopold, "Zur Szenographie der Türkenoper"; Helen Greenwald, "Picturing Cio-Cio-San: House, Screen, and Ceremony in Puccini's Madama Butterfly," Cambridge Opera Journal 12 (2000): 237-59; and Ralph P. Locke, "Beyond the Exotic: How 'Eastern' is Aida?" Cambridge Opera Journal 17 (2005): 105-39, esp. 109-11, 129 (dance, sets, pageantry, blocking), $116-24$ (costumes, wild hair, staring eyes).

$4^{8}$ See note 34 .

49 "créer progressivement une tension et un intérêt, au risque de commencer faiblement l'acte pour le finir comme un coup de fouet" (Sylvie Bouissou, "Les Indes 
section-though containing no traits of interest to the Exotic-Style Paradigm-is crucial to the portrayal of the central character, the Incan high priest Huascar. In it, he tries to manipulate the Incan maiden Phani, claiming that Heaven ordains that she marry him. Several phases in the drama of this section are revealing of Huascar and the oppressive non-Western social structure that he represents. In Example 1, Huascar sings a short aria that-as Cuthbert Girdlestone puts it in his book on Rameau-conveys the Incan tyrant's "blustering and domineering character." Through short scalar fragments and largish leaps, and of course through the words, Huascar tells Phani that "we"-in other words, she -must obey the will of heaven sans balancer (i.e. without taking a moment to think for herself). $5^{\circ}$ The quasi-imitative texture of this aria seems also to symbolize-in this context-the very act of blind obedience that Huascar is demanding of Phani. At times Huascar "obeys" the strings, at times they echo him, and this somewhat mechanical procedure feels, in the context of his rhetorical onslaught, coercive. ${ }^{1}$

Huascar here shows himself to be an unworthy ruler, abusing his religious authority for purely personal gain. His intended conquest of Phani is roughly equivalent to the lust for wealth or power of other such tyrant figures, whether exotic or European. But tyrants from Eastern regions or the New World tend to display other deplorable behaviors as well, such as blind rage, jealousy, or excessive interest in the charms of the opposite sex. In the case of Muslims, drunken excess is often presented as hypocritical flouting of Koranic strictures against imbibing alcohol. (In works set in the West, such disgraceful actions and profound character flaws are often assigned to servants and other people of modest estate. Aristocratic rulers, by contrast, are generally portrayed as following the principles of Aristotelian ethics, such as

galantes," in booklet of the Christie recording, 15). Marie-France Beziers and Philippe Beaussant sense the importance of Huascar's aria but do not discuss it in detail; they note that "l'acte commence un peu lentement ... . et s'anime progressivement, jusqu'à l'air de maxime 'Obéissons sans balancer', d'Huascar" (Rameau de A à Z, ed. Philippe Beaussant [Paris: Librairie Arthème Fayard/IMDA, 1983], 188).

$5^{\circ}$ Cuthbert Girdlestone, Jean-Philippe Rameau: His Life and Work (London: Cassell, 1957), 330-31. The back-and-forth motion in the music may also reflect the image implied in the verb "balancer." In the trio for Phani, Carlos, and Huascar near the end of the entrée, Huascar is recognizably the same character but here reduced to grumbling (or raging, as the singer must determine) that things are not going the way he planned. As Paul-Marie Masson explains, this is a rare example (for the 1730 in France) of a trio divergent, in which one of the characters sings music different from that of the other two (L'Opéra de Rameau [Paris: Henri Laurens, 1930], 280-84).

${ }^{5^{1}}$ In the DVD conducted by William Christie, Huascar begins to threaten Phani physically as this scene proceeds; he even mimes the act of slitting her throat as she, briefly despairing, lays her head atop the golden altar. 
THE JOURNAL OF MUSICOLOGY

EXAMPle 1. Rameau, Les Indes galantes (1735), scene 3, "Obéissons sans balancer": Huascar uses motivic imitation to solicit Phani's obedience. Examples 1 and 2 are based on Rameau, Oeuvres complètes, vol. 7, ed. Charles Malherbe (Paris: A. Durand et fils, 1902), which modernizes the notation and adds some dynamics and continuo figures.
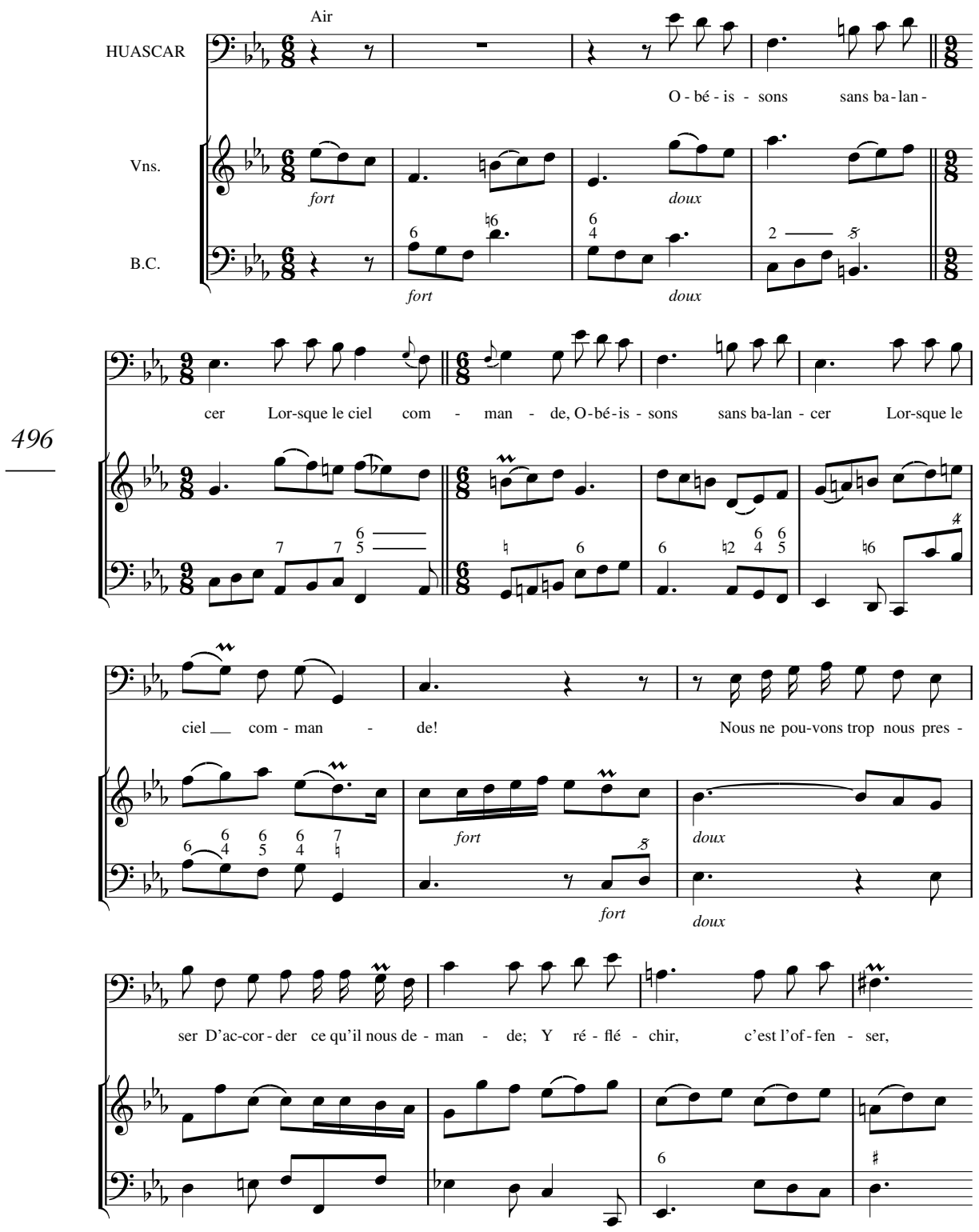
generosity, courage, and emotional continence.) $5^{2}$ In addition, the people of the exotic country in question are rarely shown as resenting the tyrant's oppressive rule. This suggests that they have little sense of what kingly virtues should be.

Phani now responds to Huascar's aria in a way that demonstrates either her intuitive grasp of Enlightenment rationality or the healthy influence of her Spanish soldier-boyfriend Carlos. (We heard Carlos conversing with her surreptitiously at the beginning of the entrée.) Phani states coolly-her music here is relatively unruffled-that people who speak as if they know the will of the gods are often guilty of "imposture." Huascar parries with even more emphatic claims and with excitable, angular melody: "What a heinous insult to the gods and to me!" (Pour les Dieux et pour moi, quelle coupable injure!). The librettist Fuzelier, in his preface to the libretto, worded Phani's accusation more bluntly: "imposture hidden under the sacred cloak of religion." Fuzelier thereby made as clear as he could, without risking censorship (or worse) from church and government, that Huascar-though presented within the drama as a "pagan sacrificer" (Fuzelier's term)—could also be read as standing for anyone in a religious hierarchy who abuses Divine authority for selfish ends. 53

In the final phase of this exchange (Ex. 2), Huascar reveals that he knows that Phani loves a Spanish soldier, and he invokes a native patriotism to win her away. 54

\section{HUASCAR}

C'est l'or qu'avec empressement,

Sans jamais s'assouvir, ces barbares dévorent.

L'or qui de nos autels ne fait que l'ornement

Est le seul Dieu que nos tyrans adorent.

\section{HUASCAR}

It is gold that these barbarians devour eagerly, without ever being sated.

The gold that is but ornament of our altars

is the only God that these men who tyrannize us adore.

I find Huascar's castigating words utterly remarkable. The Spanish conquerors (he accuses) are barbarians, motivated, not by belief in one

$5^{2}$ See Mary Hunter, "Mozart and Nobility," in Art and Ideology in European Opera, ed. Clive Brown, David Cooper, and Rachel Cowgill (Woodbridge, UK: Boydell, forthcoming).

53 Fuzelier's preface, in the $1735,175^{1}$, and 1761 libretti, as quoted in Catherine Cole, "Nature' at the Opéra: Sound and Social Change in France, 1750-79," 2 vols. (Ph.D. diss., Univ. of Chicago, 2003), 248-49.

54 This passage is a little ambiguous in the translation of the William Christie recording. Huascar says "our tyrants" but means "those men who exert tyranny over us." Compare Huascar's phrase "nos vainqueurs" (see n. $5^{6}$ ) and also, for another use of tyran, the spot in the first entrée, scene 3, in which Emilie reports to her beloved husband, whom shipwreck has brought to the same Turkish palace, that they are not free to reunite because the sultan has taken a liking to her: "Mon tyran m'aime," i.e., the man in this country who lords it over me desires to bed me. 
THE JOURNAL OF MUSICOLOGY

EXAMPle 2. Rameau, Les Indes galantes, scene 3, "C'est l'or qu'avec empressement": musico-rhetorical devices in Huascar's anticolonialist tirade
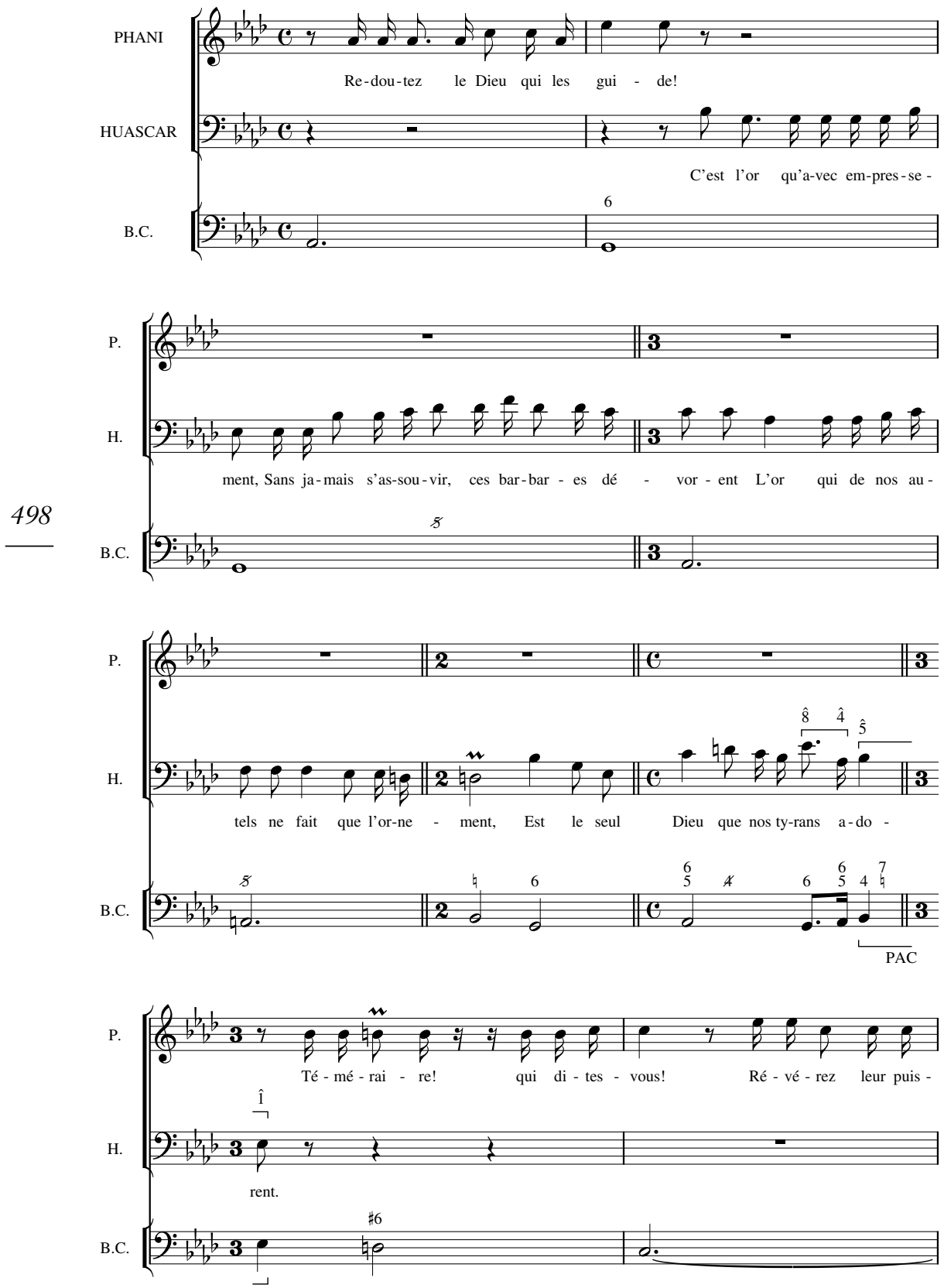
God and in salvation through Christ (as they claim), but by greed. Phani had used the powerful word barbares minutes before when warning Carlos that the Incas were violent and might do him harm if he tried to have her flee with him. Now Huascar applies the same word to the supposedly civilized Europeans. 55 Not by chance, Rameau places it (or, rather, its first syllable) on the baritone's eloquent high F. He then brings Huascar's prosecuting statement to a forceful close with what is, within the context of Rameauian recitative, a rhetorically emphatic cadence: two successive falling fifths in the voice part $(\hat{8} \hat{4} \hat{5} \hat{i})$, over a strong linear bass ascent $(\hat{3} \hat{4} \hat{5})$ ending in a perfect authentic cadence ("PAC" in Ex. 2).

All of these details help portray Huascar as an aggrieved, untiring, and-at least at this point-increasingly persuasive representative of a colonized non-European people, an agitator against the oppressor. $5^{6}$

The nobility of Huascar's stance, however, is corrupted by his "furious love" (as he puts it) for a young woman with no political power. 57 Huascar eventually rolls a boulder into a volcano, thereby setting it into eruption. (He plans to scare Phani into running to safety with him.) Enlightenment writers would have not hesitated to call this an act of "terror" typical of despotic governments. $5^{8}$ Huascar is here attempting to exploit the ignorance of Phani and the other Peruvians by appealing

55 French and British writers in what historians now call the Early Modern Era regularly portrayed the Spanish conquistadores as, essentially, "bad imperialists." Our government, army, and church, the writers imply, would do the job in a more civilized and tolerant manner. See Whaples, "Early Exoticism Revisited," 8-9. William Davenant's opera The Cruelty of the Spaniards in Peru (whose music is lost) "ends with the fortuitous arrival of the English, who save Peru from further colonial depredations at the hands of the Spanish"from Janet Clare's introduction to her edition of the full libretto, in Dramas of the English Republic I 649-6o (Manchester: Manchester Univ. Press, 2002), 235. Cf. William S. Maltby, The Black Legend in England: The Development of Anti-Spanish Sentiment, 1558-1660 (Durham: Duke Univ. Press, 1971).

$5^{6}$ He describes the Spaniards (to Phani) as "nos vainqueurs inhumains" and complains, in the first of his grand invocations to the [God of the] Sun, that "they have destroyed Your lofty refuges [on a détruit tes superbes asiles]"; I take this as a castigation by the Incan leader of the Spaniards' destruction of his people's native temples. Phani had already indicated (to Carlos) that the Spanish had driven the Incas off much of their own land: "Sur ces monts, leurs derniers asiles, / La fête du Soleil va les rassembler tous."

57 Indeed, in that same "aside," Huascar admits that unleashing the volcano is a "barbarous procedure" (or trick) that will devastate his people's lands and lives ("un barbare artifice, qui de flamme et de sang inondera ces lieux").

$5^{8}$ Montesquieu (1748): "Harsh sentences are better suited to despotic government [such as in China or the Ottoman Empire]-whose principle is terror-than they are to monarchy and republic, which have, as a driving force [ressort: literally, spring-mechanism], honor and virtue" (Montesquieu, De l'esprit des lois [Paris: Librairie Garnier frères, 1927], 1:79-8o). A few decades later, during the French Revolution, terreur and terroriste would be used actively by writers at both political extremes, e.g. in a quotation from Joseph de Maistre's Considérations sur la France (1796, p. 5) regarding Robespierre. See entries for terreur/terrorisme/terroriste in Le Trésor informatique de la langue française: <http://atilf.atilf.fr/ tlf.htm> (accessed April 27, 2007). 
to their fear of Divine retribution. Furthermore, he is strikingly juxtaposed with the rational man of science (Carlos), who explains the workings of nature to Phani in order to empower her and unmask Huascar.

Before the cataclysm begins, Carlos appears and reveals to Phani Huascar's heinous act. Phani, her eyes now open, rejects Huascar one last time. The evildoer now recognizes-in accordance with the standard Enlightenment plot of "the tyrant corrected"-that he has betrayed the ethical injunctions of his own religion. Or, as Enlightenment thinkers might have said, the ethical injunctions of all religion, all proper philosophy. Catherine Cole notes a likely endotic message that is yet more specific than the one noted earlier regarding Huascar's claim to know the gods' will. Huascar's manipulative use of his scientific knowledge, Cole points out, "perfectly illustrates the Enlightenment stereotype of a corrupt priest (within any religion), a clergyman who manipulates his people by abusing their credulous 'superstition' concerning the natural environment." 59

Thanks to Carlos's scientific savvy, the natives and the Spaniards run clear of the cascading lava, while the orchestra plays an extended passage that is heard, in context, as rumbling and dangerously surging (not as Incan). Huascar sacrifices himself under the molten flow, thereby restoring, it is implied, the social order. One final time in this entrée, the portrayal of the doings, and undoing, of a mostly nefariousbut also briefly admirable-exotic leader has been deepened and intensified by music that the "Exotic Style Only" Paradigm cannot encompass but the "All the Music in Full Context" Paradigm can.

\section{Handel's Semi-Comic Eastern Tyrant}

Les Indes galantes was set in the recent past. More often, Baroque-era portrayals of the non-European Other were set many centuries back, or even a millennium or two. But, as one historian of Arabic literature, Peter Bachmann, has argued, this does not mean that the portrayals did not also echo contemporary attitudes toward non-Europeans. ${ }^{60}$ Handel's dramatic oratorio Belshazzar of 1745 retells the Biblical story of the morally depraved king of Babylon and his hatred of the Jews, who are

59 Cole, " 'Nature' at the Opéra," 261. Cf. Catherine Kintzler, Théâtre et opéra à l'âge classique: Une familière étrangeté (Paris: Fayard, 2004), 185-93 (arguing that, in the course of the 18th century, a quasi-realistic and morally charged exoticism gradually takes the place of the typical Baroque emphasis on the marvelous).

6o Peter Bachmann, “'From Arabia's Spicy Shores': Orient in Händels Textvorlagen," in Göttinger Händel-Beiträge 8 (Göttingen: Vandenhoeck \& Ruprecht, 200o), 1-14. Bachmann, with regard to oratorios (as opposed to operas), focuses more on positive stereotypes. Solomon, for example, he sees as representing not just the Biblical king but also the philosophically inclined poet-sultan encountered in Arabic and Turkish literature of recent centuries. 
here presented (in accordance with longstanding church doctrine) as forerunners of Christianity. ${ }^{6}$ Some commentators, such as Gerhard Schuhmacher, focus on the balance of tragic and comic aspects in the portrayal of Belshazzar (both in the libretto by Charles Jennens and in the musical features mobilized by Handel in setting it). Others, notably Ruth Smith, have assessed the portrayal's echoes of mid 18th-century English political struggles. By contrast, a third aspect, the exotic, has been barely considered.

Winton Dean surely points in the right direction when he notes that Jennens's libretto presents Belshazzar's court as "a riot of oriental colour-wives, concubines, astrologers, and all." Dean could have stated more explicitly that these images from the oratorio were and are recognized as "Oriental" because they are found also in such writings as the Thousand and One Nights. (This collection had become widely known in Handel's day through the French translation of Galland and its various English adaptations. ${ }^{62}$ Belshazzar, Dean adds, is introduced to us as a "sottish self-indulgent [Oriental] tyrant" even before we get to meet him. Gobryas, whose son was one of Belshazzar's recent victims, decries the tyrant in a memorable aria: "Behold the monstrous human beast / Wallowing in excessive feast! / . . . Self-degraded to a swine. /... grov'ling on the ground." Handel's music for the oft-repeated opening words (Ex. 3) nicely conveys what Dean calls the tyrant's "swaggering gait." 63

The coloratura passages (end of Ex. 3) provide a clear instance of what I described earlier with regard to the Full-Context Paradigm and melismas: the more or less generic up-and-down alternations take on specific associations because they are sung to the repeated word "wallowing." One thus easily imagines the "self-degraded" Belshazzar cavorting in mud, this way and that.

Equally vivid, and more plainly linked to then-prevailing images of the Middle East, is Handel's setting of the passage in act 2 in which the cruel, cowardly despot urges his courtiers to join him in drinking wine served in vessels that the Babylonian troops had stolen from King

61 On the Christian implications-and the contemporary political implications, within England-of various aspects of the Old Testament story (Daniel, the book of Isaiah, the Temple vessels as forerunners of the Eucharist), see Ruth Smith, Handel's Oratorios and Eighteenth-Century Thought (Cambridge: Cambridge Univ. Press, 1995), 152-53, 261-67, 304-34, 317-19; further on Jennens, see Smith, "The Achievements of Charles Jennens, 1700-73," Music and Letters 70 (1989): 161-9o (esp. 184).

62 Winton Dean, Handel's Dramatic Oratorios and Masques (London: Oxford Univ. Press, 1959), 434-59. The basic source for many 18th-century published translations and adaptations of the Thousand and One Nights was Les mille et une nuits, trans. Antoine Galland (Paris: Barbin, 1704-17), though it was unreliable in many ways, as Irwin and Beaumont explain (see note 30 ).

63 Dean, Handel's Dramatic Oratorios, 440. 
THE JOURNAL OF MUSICOLOGY

EXAmple 3. Handel, Belshazzar (1745), Act 1, Gobryas's aria "Behold the monstrous human beast!", with musical suggestions of Belshazzar's "swaggering gait" and (in the melisma) the lolling motions of a "swine." Examples 3 and 4 are based primarily on the recent critical edition (in piano-vocal score), ed., Donald Burrows (London: Novello, 1993).
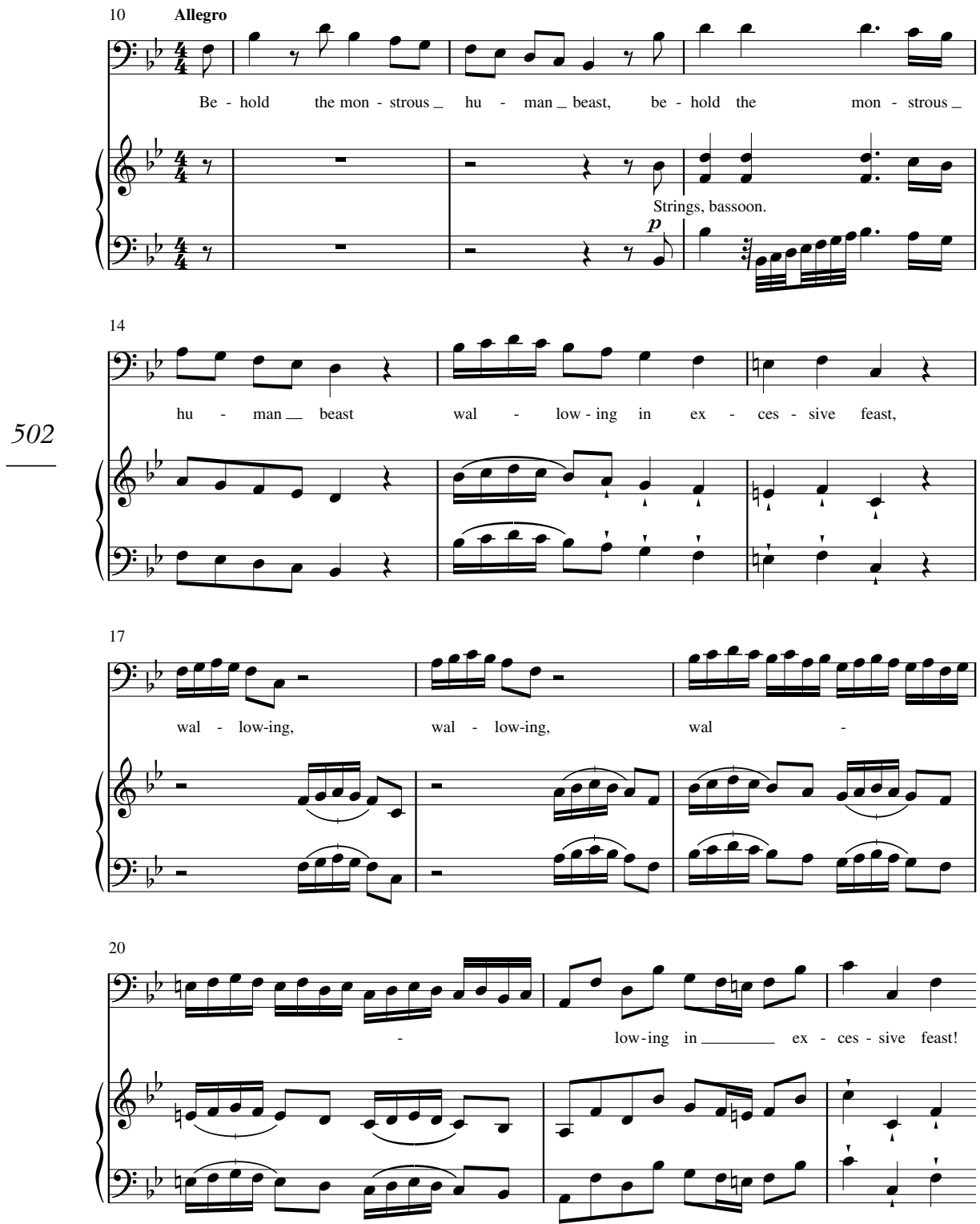
Solomon's great Temple. The words with which Belshazzar calls for more wine border on the blasphemous. The Babylonian king here imagines himself becoming godlike-not by virtuous behavior but by indulging to excess in fermented beverage:

Another bowl!-_'tis gen'rous wine,

Exalts the human to divine.

Handel's rising vocal scale on "Exalts the human to divine" (see Ex. 4) audibly mimics Belshazzar's claim of elevating himself to godhood. As for the phrase "Another bowl!"- set as a spirited arpeggiated drinking "call" ${ }_{4}$-Handel states it four times, each time echoed by the oboes as if to allow for imagined stage action: Belshazzar grabbing and swigging one cup after another. ${ }^{6}{ }_{5}$ And the melismatic passage (ultimately rising to a long-held G on "exalts") is one of those instances, discussed earlier, that, though not specific to the situation, is "read" in context as the natural culmination of the process by which a character reveals his or her merit (or lack of merit). Belshazzar here shows how caught up he is in drunken grandiosity (the tenor can feel free to fling out that high note) and how determined a foe to the (incipient) West and its religious traditions.

This richly "visualized" and musicalized moment demonstrates concretely what Gobryas's aria has already, in words and music, described. The whole episode links Belshazzar to stereotypical images of Middle Eastern sultans enjoying a selfish life of opulence and pleasure and, at times, engaging in hostile acts against Europe and Europeans (or, here, proto-Europeans) ${ }^{66}$ I wonder whether John Beard, the tenor who sang

${ }^{6} 4$ Such arpeggiated phrases are found in various convivial songs of the era, such as (the opening of) John Blow's 'Tis Women Makes Us Love, performed by the Merry Companions on the Baltimore Consort's recording The Art of the Bawdy Song, Dorian CD 91055. This suggests that contemporaries would have found the music of Belshazzar's aria compatible with the words and situation (a drinking song).

${ }_{65}$ Gerhard Schuhmacher comments on the "rising line which is plainly perceived [by the ear]" in this very passage as one instance of a portrayal "full of buffoonery" but does not mention the visual image created when (as noted above) the phrase "Another bowl!" is stated four times ("George Friedrich Händel, dramatisches Oratorium Belsazar: Eine Einführung," 5, in the booklet to the 1976 Nikolaus Harnoncourt recording, with Robert Tear, Teldec 6.35326-oo-501). Schuhmacher also refers to the "tragikomisches Stammeln" (tragicomic stammering) of Belshazzar's wise men after the mysterious hand writes on the wall.

66 The Thousand and One Nights involve a number of tales of drunkenness and sexual debauchery. The valuable index of themes in the Nights by Nikita Elisséeff lists numerous instances of drunkenness, incest, couples caught in flagrante delicto, "pederasty" (Elisséeff finds six such instances), "feigned pederasty" (two instances), and drug-induced stupors-Thèmes et Motifs des Mille et Une Nuits: Essai de Classification (Beirut: Institut Français de Damas, 1949), 85-205. For centuries, Westerners portrayed the prophet 
THE JOURNAL OF MUSICOLOGY

EXAmple 4. Handel, Belshazzar, Act 3: Belshazzar's aria "Let the deep bowl thy praise confess" (passage beginning "Another bowl!"). The Babylonian tyrant calls for multiple cups of wine, and rising lines mimic the "godlike" feeling that results.
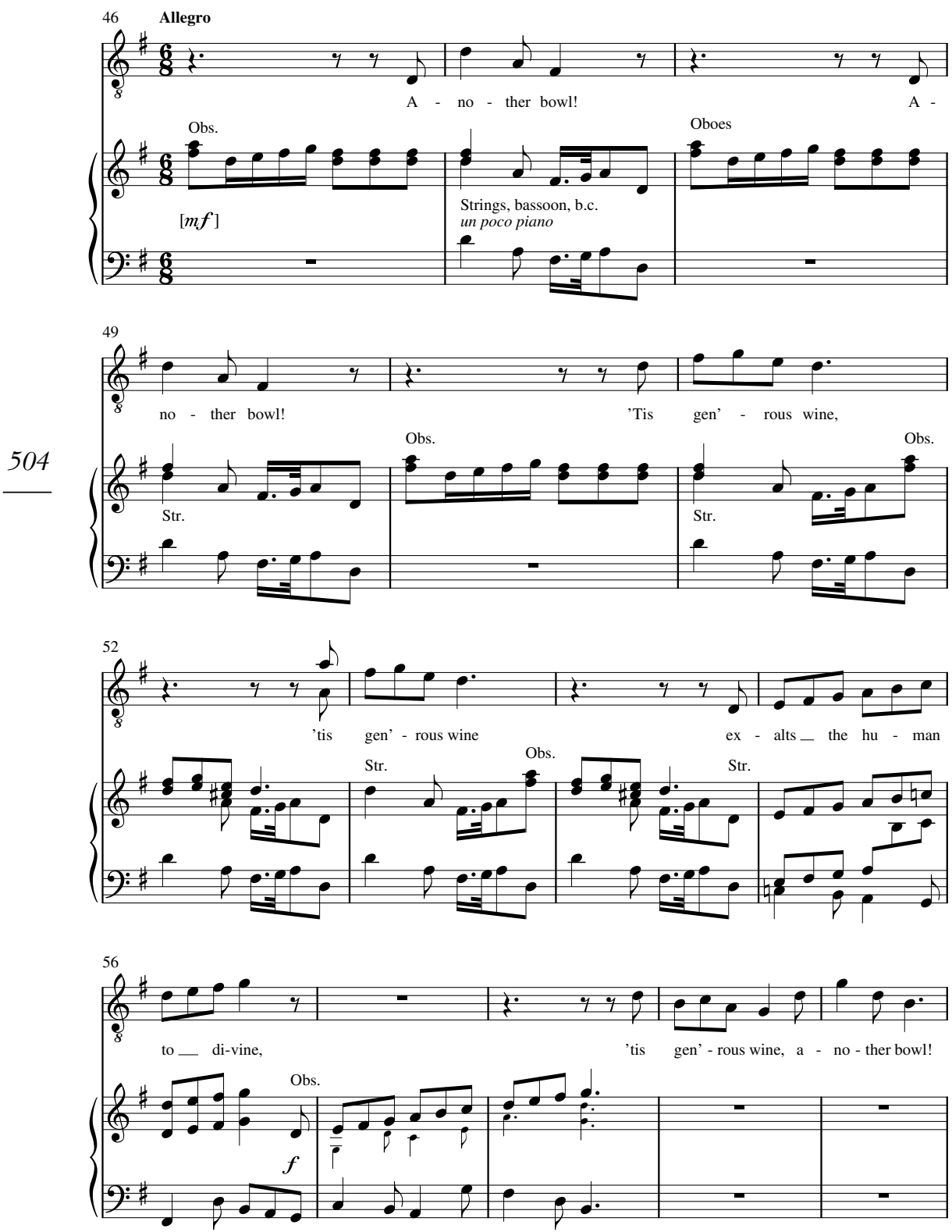
the role at the first performances, emphasized the ruler's reckless excess by reaching for a second wine bowl (invisible, this being an oratorio) and then a third, fourth, and fifth. ${ }^{67}$

\section{Exoticism and Empire}

One broad contextual consideration that I have only hinted at thus far is an essentially political one: how the West, in Rameau's and Handel's day, was coming to exert power over distant and different populations. Huascar and Belshazzar plainly portray the deficiencies of nonWestern regions and their leaders. They thereby suggest the essential rightness of European rule over, respectively, the New World (where France, at the time, held major profitable territories, notably in Canada, greater Louisiana, and the Caribbean) and "the East" (which, for England, meant first and foremost India). ${ }^{68}$

To be sure, Huascar and Belshazzar may have been read at the time as metaphors of "the unjust leader" more generally. This point is made rather directly, with regard to Huascar, in the passages already cited from Les Indes and Fuzelier's preface. As for Belshazzar, the librettist, Charles Jennens, later reminisced in a letter to a friend that he had had a "farther aim" in proposing the Belshazzar libretto to Handel. Scholars reasonably surmise that Jennens was referring to his own confirmed opposition to the corrupt Whig government of the Hanoverian king, George II. (Jennens wrote numerous brochures explicitly advocating the Non-Juror position, which envisioned bringing back the Stuartsthough not Catholicism. ${ }^{69}$ But this hidden endotic reading does not invalidate the surface-level exotic one. Jennens made his religio-political point precisely by engaging the available stereotypes of overprivileged, dissolute Eastern monarchs. In the process, he disseminated and (in conjunction with Handel's genius) reinforced those stereotypes.

It is perhaps ironic that, over the succeeding centuries, Jennens's political take on Belshazzar-as symbolizing the worst aspects of

Muhammad, in particular, as lascivious; see Norman Daniel, Islam and the West (Edinburgh: The [Edinburgh] University Press, 1958), 4, 238, 274-75; and Nasser Al-Taee, "The Sultan's Seraglio: Fact, Fiction, and Fantasy in Eighteenth-Century Viennese 'Turkish' Music" (Ph.D. diss., Univ. of California at Los Angeles, 1999), 89-132.

${ }_{67}$ Stage performers in this era mastered an extensive vocabulary of gestures, bodily positions, and facial expressions. Less clear is how extensively these may have carried over to sacred oratorio (despite the absence of costumes, sets, and onstage action).

68 On possible connections between exotic operas and British overseas commercial interests at the time, see Ellen T. Harris, "With Eyes on the East and Ears in the West: Handel's Orientalist Operas," Journal of Interdisciplinary History 36 (2006): 419-43.

69 See his letters to Edward Holdsworth, quoted in Smith, "Achievements," 184 ; also in Smith, "Handel's English Librettists," in The Cambridge Companion to Handel, ed. Donald Burrows (Cambridge: Cambridge Univ. Press, 1997), 108. 
Whigdom-faded for audiences and commentators. Only in recent decades has it been patiently reconstructed by devoted scholars. By contrast, the reading of Belshazzar as a typically self-centered and selfindulgent Eastern ruler remains as potent as ever for performers and audiences, embodied as it is more or less directly in words and noteseven though those notes do not (as the "Exotic Style Only" Paradigm would require) sound "Eastern."

\section{The Gypsy Carmen's Non-Gypsyish Lament}

When we jump a century and a half, we leap over the years in which the (unofficial, never published) lexicon of identifiable exotic styles-alla turca, Scottish, Hungarian-Gypsy, Middle Eastern, and so on-was established. Bizet's Carmen therefore can include copious amounts of something that we did not find in the Handel and barely in the Rameau: music that "sounds like" that of the place being depicted. Spanish and Spanish-Gypsy (flamenco) traditions are notably evoked in five of Carmen's solo pieces from acts 1 and 2: the Habanera, her taunting "Tra-la-la" song, the Séguedille, the "Chanson bohème," and her wordless song and dance with castanets. Escamillo's Toreador Song (in act 2) and the entr'acte to act 4 are likewise amenable to an Exotic-Style Paradigm analysis. $7^{\circ}$ The Full-Context Paradigm can encompass these seven numbers, of course (because it fully contains the Exotic-Style Paradigm), but also can help us notice others numbers in the work that, though not sounding Spanish or Gypsy, patently reinforce the portrayal of various (supposed) Spanish and Gypsy traits. A fascinating and underexamined instance is Carmen's soliloquy in the middle of the act 3 Card Trio.

It may seem risky to explore the meaning of style in any number that Carmen sings. Rather like Mozart's Don Giovanni, she shifts her musical style depending on the individual or group being addressed. Most notably, Carmen has mastered the art of echoing the Gounod-like lyrical-passionate manner of Don José. In Susan McClary's apt term, she "baits" him with it in the middle of the otherwise Spanish-sounding Séguedille. He takes the bait, repeating the melody and even oneupping her in vocal range. $7^{1}$

$7^{\circ}$ On the Séguedille scene and the entr'acte to Act 4, see my "Spanish Local Color." On all seven Spanish-style numbers, see Winton Dean, Bizet, 3rd ed. (London: Dent, 1975), 228-32; and Hervé Lacombe, Georges Bizet: Naissance d'une identité créatrice (Paris: Fayard, 2000), 690-701.

${ }_{71}$ Carmen sings "Qui m'aime ... " in A major, climaxing on a high $\hat{6}$; José repeats her music ("Ta promesse ...") in B major, and extends the line up to a high $\hat{\eta}$. See Susan McClary, George Bizet: Carmen (Cambridge: Cambridge Univ. Press, 1992), 87-89. McClary 
One number, though, the Card Trio, shows us Carmen without guile. Frasquita and Mercédès have just playfully told their fortunes with a deck of cards. Our heroine takes the deck, starts turning cards over, and is stunned by what they predict: death for herself and then for José. Her ensuing musical soliloquy, sometimes called the "Card Aria," has been discussed perhaps one tenth as frequently-and in one-tenth the level of detail-as the Habanera, no doubt precisely because it is devoid of Hispanic or Gypsy musical color. Yet the number, as various critics have noted (including Nietzsche and, in a detailed discussion, Adorno), gives voice to Carmen's deepest concerns through words and music. $7^{2}$ Whereas so often Carmen performs for one person or a crowd-diegetically, as one says in the language of film criticism-this time she is alone with her thoughts. 73

The Card Aria resonates with a different stereotype than do Carmen's sexy, teasing, life-affirming numbers earlier in the opera. The stereotype here is of the Gypsy as superstitious and irrationaloppressed by fear of fate, as told by a deck of cards. 74 This is immediately apparent from the words:

A voix basse, tout en continuant à mêler les cartes.

En vain, pour éviter les réponses amères,

En vain tu mêleras!

Cela ne sert à rien, les cartes sont sincères

Et ne mentiront pas!

Dans le livre d'en haut si ta page est heureuse,

Mêle et coupe sans peur.

La carte sous tes doigts se tournera joyeuse

T'annonçant le bonheur.
Quietly, while continuing to shuffle the cards.

Try though you may, to avoid bitter outcomes,

You shuffle in vain!

Nothing comes of it. The cards are truth-tellers

And will not lie!

If your page in the book on high predicts good luck,

Shuffle and cut without fear.

The card under your fingers will turn up smiling,

Announcing happiness.

rightly stresses Carmen's ability to pass as a Spaniard-to pretend not to be a Gypsy. In so doing, McClary is still, it seems to me, working within the Exotic-Style Paradigm (focusing on the exotic-Spanishness of certain numbers, though insightfully stressing that they are mostly without specific exotic-Gypsy coloration).

$7^{2}$ Hugo Daffner, Friedrich Nietzsches Randglossen zu Bizets Carmen (Regensburg: G. Bosse, [1912]), 15, 53-55 (Nietzsche describes the aria's opening as "fatalistic music"; certain details are "abrasive yet pleasant" and "totally spooky"); and Theodor W. Adorno, "Fantasia sopra Carmen" (1955), in his Quasi una fantasia: Essays on Modern Music, trans. Rodney Livingstone (London: Verso, 1992), 53-64.

73 McClary, George Bizet: Carmen, 101 ; and Parakilas, "Soldier," 33, 45-47. 166.

74 Cf. James Parakilas, "How Spain Got a Soul," in Bellman, Exotic in Western Music, 


\section{THE JOURNAL OF MUSICOLOGY}

Mais si tu dois mourir, si le mot redoutable

Est écrit par le sort,

Recommence vingt fois ... la carte impitoyable

Répétera: la mort!
But if you must die, if the terrible word

Is written by Fate,

Start again twenty times-the pitiless card

Will repeat: Death!

Lesley Wright notes that the music, "with its repeated tones, minor modality, and low[-] pitched heavy brass chords, specifically the funereal trombones, evokes the mode of expression used by the oracles of death in French operatic history."75 I would add that the vocal melody states a four-bar rhythmic pattern almost identically six times in a row and the beginning of a seventh-somewhat like a medieval talea-heedless of shifts in the melody's pitch content and swerves in the orchestra's harmony (Ex. 5). $7^{6}$ The rigid rhythmic pattern derives its distinctiveness from three factors: 1) its almost total restriction to even eighth notes; 2) a striking incongruity between the uneven-length poetic lines and the music's regular four-bar pace;77 and 3) the extending of the talea beyond the downbeat. $7^{8}$

Bizet indicates that the aria should be performed simplement et trèségalement (simply and very evenly).79 And, except as it nears its end, he

75 Lesley A. Wright, "Profiles in Courage: Two French Opera Heroines," Fu Jen Studies: Literature and Linguistics 30 (1997): 66.

$7^{6}$ A similar uninflected rhythm marks the vocal line of another near-catatonic visionary in the musical repertoire: the persona of Schubert's "Der Leiermann" (the final song in Winterreise, 1827). But there it is not associated with any exoticness-though perhaps the hurdy-gurdy man's tune in the piano is marked by Hungarian-Gypsy style, as Jonathan Bellman proposes in The style hongrois in the Music of Western European Music (Boston: Northeastern Univ. Press, 1993), 154-58.

77 The lines alternate between 13 syllables-if one counts the final, "mute" $e$-and six syllables; or, in French parlance, between a feminine alexandrine and a hemistich. Steady eighth-note declamation occurs, but only for four or eight measures (and in $\mathbf{2}$ meter, not $\mathbf{3}$ ), in two situations in Verdi in which a female character is being resolute (Gulnara, in $\mathrm{Il}$ corsaro, act $\mathrm{g}$ duet) or indicating a new-found calmness (Leonora in La forza del destino, act 2 duet with the padre guardiano). See David Rosen, "Meter and Testosterone: Preliminary Observations about Meter and Gender in Verdi's Operas," in Una piacente estate di San Martino: studi e ricerche per Marcello Conati, ed. Marco Capra (Lucca: Libreria musicale italiana, 2000), 184-85, 202-3. For further instances of melodies that are clothed in durations of equal length for a line or two (but not 14!), see Friedrich Lippmann, Versificazione italiana e ritmo musicale: rapporti tra verso e musica nell'opera italiana dell'Ottocento (Naples: Liguori, 1986), 184. As for a verse meter that alternates between a long line and a short one, this was typical of many 19th-century ghazăl-inspired "Orientalist" poems, such as those by Goethe that were set by Schubert and Wolf and those by Théophile Gautier that were set by Félicien David (e.g., the latter's Sultan Mahmoud, 1845, alternating seven syllables and four).

$7^{8}$ A separate aspect of characterization: Bizet seizes the opportunity to add a sorrowful appoggiatura to several of the half- and full cadences, noticeably on the words "et ne mentiront pas."

79 In some 2oth-century scores this was translated, a bit wanly, as semplice, ben misurato. 
EXAmple 5. Bizet, Carmen, Act 3 (1875): beginning of the "Card Aria," marked to show the lengthy recurring rhythmic pattern in the melody and the un-mute treatment of the "mute $e$." Based primarily on the recent critical edition (in pianovocal score), ed. Robert Didion (Mainz: Schott. 200o)
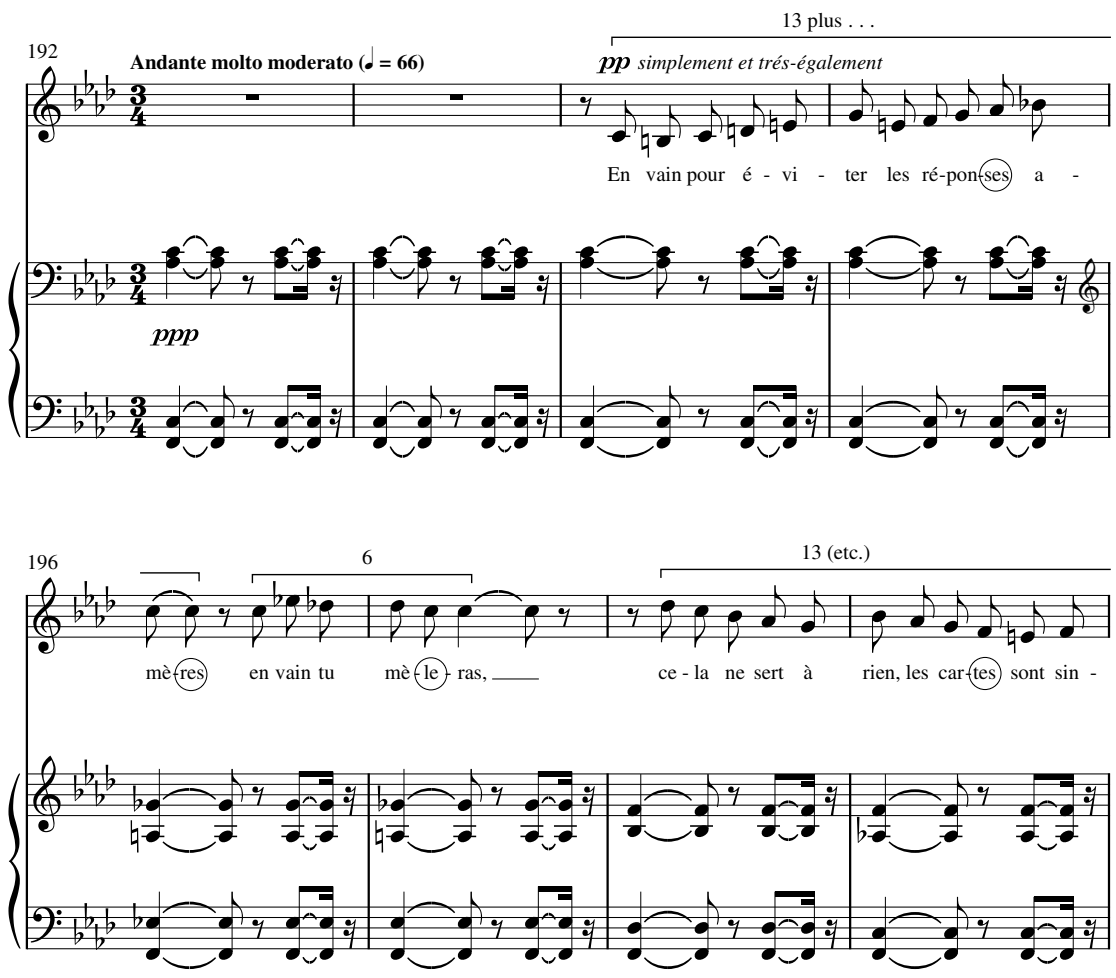

requests that it proceed in a more or less unrelenting tread, without highly personal or spontaneous-sounding application of rubato. Bizet does mark numerous important changes in dynamics-across the whole range from pianissimo upwards-but these presumably are meant to occur in tension with the unyielding rhythm. Carmen, I conclude from this, is trapped by the implacable pulsing in her brain-by her belief that she is doomed-and struggles against it, unable to break from the confining fatalism of her (ultimately non-European, "primitive") culture. ${ }^{80}$

8o Effectively, she is singing her own funeral march, but in $\mathbf{4}_{\mathbf{4}}^{\mathbf{3}}$. Triple meter is more often used for waltzes or other dances (such as Carmen's Gypsy chanson at the beginning 


\section{THE JOURNAL OF MUSICOLOGY}

In the final minute or so of her aria, Carmen breaks briefly from the confines of her talea. She ascends to a fortissimo high F (I mean, a mezzo's high F). Bizet even allows her one measure of rhythmic freedom (he tells the orchestra to play colla voce) ${ }^{81}$ During this passage of climax and release, Carmen actually runs out of new text to sing, because the librettists offered Bizet only six poetic couplets, not eight. ${ }^{82}$ As a result, whereas the general rule in early to mid 19th-century operatic arias is for the character to recall previous lines and phrases only in the coda, Carmen already starts freely repeating the most recent words during the culminating measures of the aria tune proper. By repeating, to increasingly intense music, words that themselves involve the verb "repeat"- "la carte impitoyable répétera la mort"-Carmen seems to be coming under the hypnotic spell of that pitiless card of doom.

The Card Aria thus conveys ethnic or exotic characterization without ethnic or exotic style, in ways that the "All the Music in Full Context" Paradigm permits us to grasp and explore. I would go so far as to suggest that, paradoxical though it may seem, Carmen comes across in this aria as more deeply "a Gypsy" than in her patently Gypsy numbers earlier in the opera.

The Full-Context Paradigm, though, does not insist that Carmen is only a Gypsy, any more than the Exotic-Style Paradigm does. Musicodramatic scenes, as opera critics have long recognized, can operate on several levels at once, permitting "both/and" readings rather than a more constraining "either/or." The Gypsy Carmen staring at her cards of doom can serve simultaneously as a locus for empathetic identification by "us" (non-Gypsies and non-Spaniards). Bizet authority Hervé Lacombe has recently termed the effect of this aria "cathartic," by analogy

of act 2 and, dancelike by implication, her "tra-la-la" song in act 1), for outpourings of romantic yearning, or, as David Rosen has noted, for somewhat blandly consolatory choruses of handmaidens ("Meter and Testosterone," 194-200, 208-9). Nonetheless, other funeral marches in triple meter are found in the repertoire, including one for chorus and orchestra by Brahms ("Denn alles Fleisch es ist wie Gras," from Ein deutsches Requiem, 1866-68) and one for piano by Shostakovich (Prelude in E-flat Minor, op. 34, no. 14, 1932-33). Those who still are uncomfortable thinking of funeral marches in triple meter may prefer to call such pieces "dirges."

81 This was standardized as poco rit. in some scores.

${ }_{82}$ More accurately, the librettists did provide a seventh couplet that Bizet declined to set, though it continued to appear in certain published librettos up to the late 2oth century. See Wright, "Profiles in Courage," 66-67, and Carmen: Georges Bizet, English National Opera Guide series 13, ed. Nicholas John (New York: Riverrun, 1982), 107. The couplet (which, in any case, does not totally match the verse meter of the previous six) has Carmen minimizing everything she has just said ("Qu'importe!") and leads the way for her to join Frasquita and Mercédès in their jolly refrain. Instead, Bizet, of course, decided to keep Carmen set apart, murmuring "La mort, toujours la mort!" and even "Désespoir!" 
with ancient tragedy. "For an instant, the performance ..., when it reaches this point of tragic experience, binds the spectator to, and then releases him [or her] from, the anguish of death." ${ }_{3}$ Even Susan McClary, who helpfully stresses the core tension of supposed "civilized" and "Gypsy" values elsewhere in this work, concludes that Carmen, by making no use of "her characteristic gypsy discourse" in this aria, shows herself to possess " 'universal' subjectivity," to be "just like everyone else." ${ }_{4}$

But, of course, Carmen is primarily, in this aria as elsewhere, presented as not being "just like everyone else." Many of us in the audience, I suspect, find ourselves able to empathize readily with this searing portrayal of a person facing her own death sentence precisely because we know that the singer up there on stage is (within the context of the plot and costumes) one of "those Gypsies": superstitious creatures who react passively to Fate (as we more rational beings supposedly do not). We thus may permit ourselves to recognize the deep human truths in Carmen's song instead of resisting them as we might have had she looked just a bit more like us and behaved more the way we (think we) do. And all of this is achieved precisely through-though the Exotic-Style Paradigm would find this puzzling-the avoidance of musical Gypsyisms or Hispanicisms.

Anti-Imperialism in Madama Butterfly?

Empire-already a significant factor in the era of Rameau and Handel-became, in the $19^{\text {th }}$ and early 20 th centuries, one of the most powerful forces (for good and ill) in world history. Britain, France, and Russia expanded their territorial reach, as did smaller players such as Belgium (in the Congo), Italy (a failed venture in Ethiopia in 1896), and, increasingly, the United States.

The question of empire may lead us back to the near-definitive instance of an exotic work (discussed briefly in the first half of this article): Madama Butterfly. Does Cio-Cio-San's fragility turn her into an exotic victim-and, more specifically, a victim of imperialism-and thereby turn all Asian women as well into victims? Susan McClary, frankly troubled by this possibility, has postulated a reading that might show how this opera, despite much evidence to the contrary, "empowers women and condemns imperialism." But, she adds, "I have difficulty imagining that Puccini in 1904 had this kind of cultural critique in mind as he penned his score." ${ }_{5}$ McClary even halfway dismisses her

$8_{3}$ Lacombe, Georges Bizet, 711.

84 McClary, Georges Bizet: Carmen, 101.

$8_{5}$ Susan McClary, "Mounting Butterflies," 2 1-35 (26). 
THE JOURNAL OF MUSICOLOGY

own proposed reading as "politically correct"-and good mainly for bolstering the career of an upwardly mobile academic. ${ }^{86}$

McClary's first instinct is more solid than she suspects. "Devastating attacks on patriarchy and imperialism" (her phrase) are clearly what Puccini and his librettists had in mind-in part. ${ }^{87}$ Certain portions of Madama Butterfly dramatize effectively the principle of respecting the worth and potential of a person whose cultural situation is very different from one's own. ${ }^{88}$

Still, Madama Butterfly is complex and contradictory. McClary's ensuing doubt is fully justified by facets of the work that have long deserved closer attention. Three ensembles show how diversely and inconsistently Puccini and his librettists portrayed Japan, its then-unfamiliar people and customs, and its new and often fraught relationship to the imperial West. (It was scarcely 5o years earlier-in 1853-that Commodore Perry and his four gunboats had "opened" Japan to the West.) All three ensembles carry out their vivid portrayals with little or no use of the copious musical markers of Japan found elsewhere in the score and therefore have been ignored, or found puzzling, by the Exotic-Style Paradigm.

The initial appearance of Butterfly and her friends in act 1 is visually spectacular. ${ }^{89}$ Dozens of kimonos and "brightly colored parasols" move gracefully up the hill to attend the wedding ceremony in Butterfly's garden.90 The music is harmonically rich (including augmented triads) and ripely orchestrated. But it is not at all Asian-sounding. This has led the scholar-conductor Julian Smith to comment that "exoticism is [suddenly] discarded" here. "[In] what in theory one might have ex-

86 McClary, "Mounting Butterflies," 27, 26 ("increase one's disciplinary capital").

87 Ibid., 27 (I have corrected an evident typographical error: "attacks of").

${ }^{88}$ Multiculturalism (as a political philosophy and program) has recently been defined as "the radical idea that people in other cultures, foreign and domestic, are human beings, too-moral equals, entitled to equal respect and concern, not to be discounted or treated as a subordinate caste." Joshua Cohen, Mitchell Howard, and Martha Nussbaum, "Introduction: Feminism, Multiculturalism, and Human Equality," in Susan Moller Okin, et al., Is Multiculturalism Bad for Women?, ed. Joshua Cohen, Mitchell Howard, and Martha Nussbaum (Princeton: Princeton Univ. Press, 1999), 4. Peter Berkowitz dismisses the book's version of multiculturalism as merely a "grandiose" restatement of classical liberalism: see his review in The Weekly Standard, November 1, 1999, now at http://www peterberkowitz.com/feminismvsmulticulturalism.htm (accessed January 30, 2007).

$8_{9}$ This scene is perhaps based on one or more Japanese woodcuts, some from the 183 os, showing the procession of a geisha and her female attendants through the Yoshiwara district. Such carefully choreographed processions helped expose a geisha to the gaze of potential clients (who, before the 185 os, would have been entirely Asian). See Greenwald, "Picturing Cio-Cio-San," 251-53.

$9^{\circ}$ As early as 1906 (Paris), productions of Puccini's opera began adding, for further local color, a small bridge and sometimes also a gateway with typically Japanese concave crosspiece. 
pected to be the exotic opportunity par excellence, ... Japan is forgotten for a moment." $9^{1}$

Quite the contrary, the "exotic opportunity par excellence" is fully exploited in this magical moment. As the "All the Music in Full Context" Paradigm makes clear, exoticism-that is, representation of an exotic land and its people-does not require the presence of exotic-sounding musical style. The librettists and Puccini here produce-even without Japanese musical motifs-an unsurpassed scopic and aural emphasis on Oriental (East Asian) feminine beauty and grace. This occurs at the level both of the group and-as the voice of the "happiest girl in Japan" soars above-of the individual (Ex. 6). The moment could be regarded as the most oppressive in the work-the most quintessentially Orientalist, in the denigratory sense. All Asian womanhood, practically, is here reduced to a vision of loveliness, as if frozen in time, for the delectation of the Western gazer.

Viewed another way, though, this idyllic scene of young Japanese women also quivers with what William Ashbrook has called "bitter irony." It begins immediately after Pinkerton's triumphant words (and music) that announce to Sharpless his plan to marry one day "a true American wife." 92 The sequence of musicalized events-Pinkerton's heartless vow, Butterfly's floating entrance and graceful landing-castigates Pinkerton's selfishness and hypocrisy. By extension, it also castigates the imperial system that has brought Pinkerton to this distant land with dollars enough in his pocket to turn matters to his own advantage.

By contrast, the ensemble that follows cannot remotely be read as engaging in a critique of imperialism. Butterfly's wedding guests look Pinkerton over and make various admiring or skeptical comments to each other, either at the same time or in canon. The resulting verbal gabble puts the audience in somewhat the same position as Pinkerton, who has already made various jokes about the incomprehensibility of the local customs. 93 The overload of instant opinions from this diverse Japanese throng is echoed in the harmonic language, which several

$9^{1}$ Julian Smith, "Musical Exoticism in 'Madama Butterfly,' " in Esotismo e colore locale nell'opera di Puccini: Atti del I Convegno internazionale sull'opera di Giacomo Puccini, Torre del Lago, Festival pucciniano I983, ed. Jürgen Maehder (Pisa: Giardini, 1985), 113.

${ }^{2}$ William Ashbrook, The Operas of Puccini, corrected ed., with preface by Roger Parker (Oxford: Oxford Univ. Press, 1985), 117.

93 He made even more such wisecracks-insulting the food, joking about the frequent bowing - in the opening-night (La Scala) version of the work. All the versions of the work's libretto are laid out in convenient parallel columns in the booklet for the CD recording conducted by Charles Rosekrans (Vox $475^{25}$, on four programmable CDs). Full documentation of the work's genesis is now available in Madama Butterfly: Fonti e documenti della genesi, Arthur Groos, ed., with Virgilio Bernardoni, Gabriella Biagi Ravenni, and Dieter Schickling (Lucca: Centro studi Giacomo Puccini, 2005). 
THE JOURNAL OF MUSICOLOGY

EXAmple 6. Puccini, Madama Butterfly (1904-6), Act 1: blissful arrival of "the happiest girl in Japan" and her friends
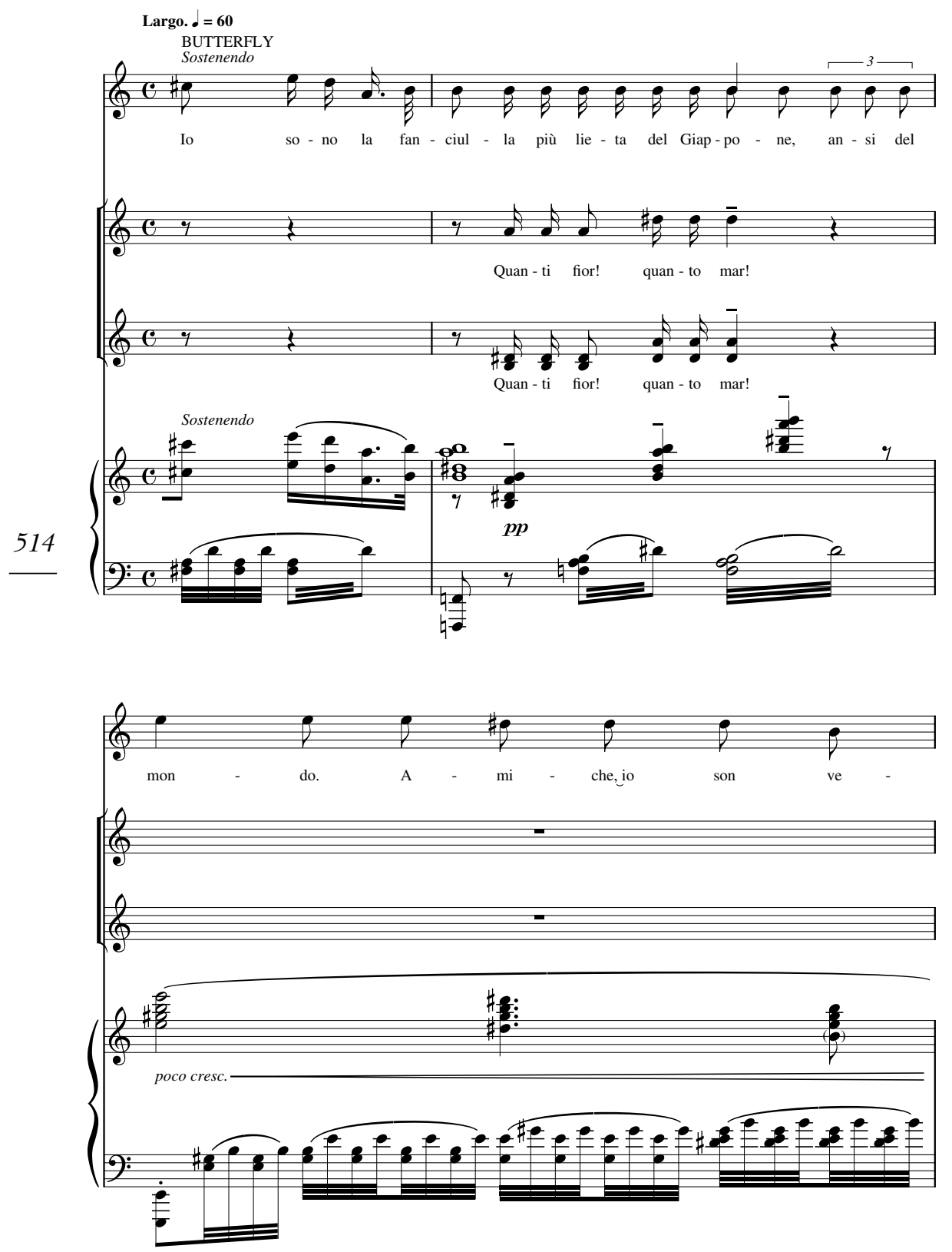
EXAMPLE 6. (continued)

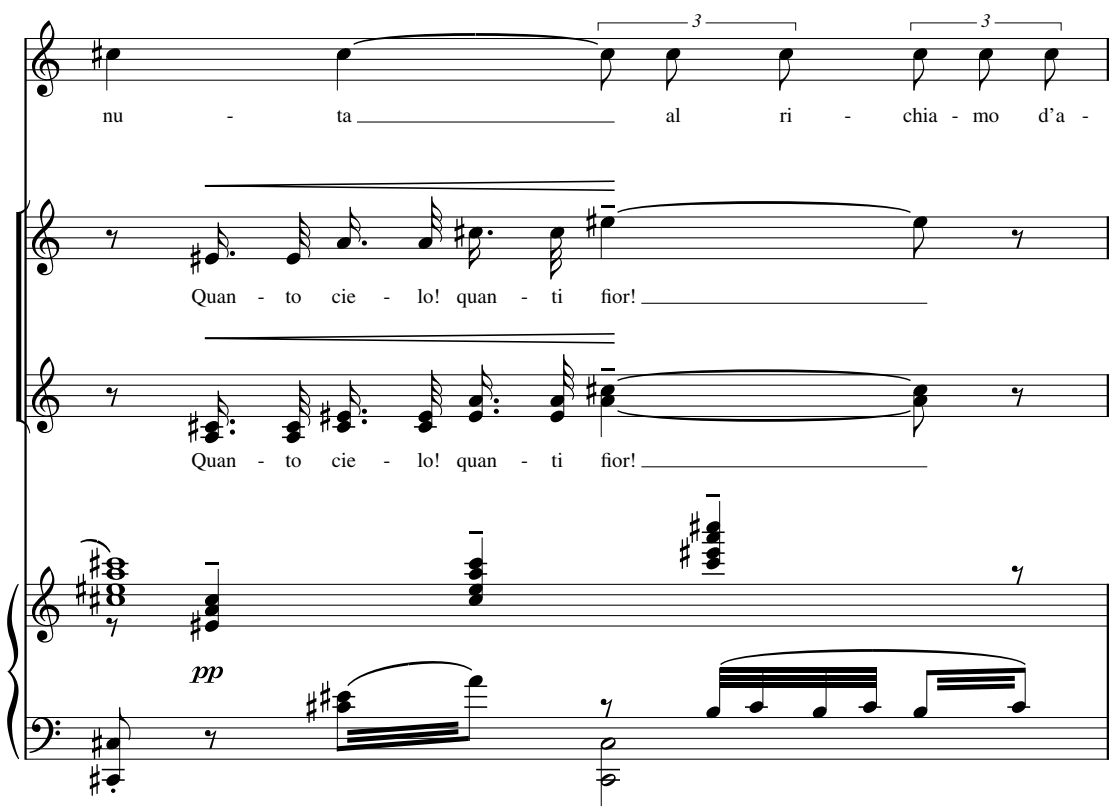

times engages in unusual levels of dissonance, e.g. three full measures built on an 11 th-chord (Ex. 7).

It might seem odd of Puccini to use the most advanced (i.e. Debussyan) harmonic tools to describe a supposedly backward Eastern society. But the 11 th-chord-in this particular context-results from the rather mechanical process of a gradual pileup. (The "processional" melody is stated several times at increasingly higher pitch levels over a static open fifth in the low instruments.) The device thus works superbly, suggesting a race of automatons who are unable to react to a newcomer with anything other than superficial conventionality and jealous lies. (The first sopranos and the Cousin: "[Goro] also offered him to me, but I answered, 'I don't want him!'”) This scene also lays the groundwork for an even more negatively skewed ensemble, only minutes later. The rigidly traditional Bonze (a Buddhist priest) enters, cursing Cio-Cio-San for having abandoned her people's religion. Wehaving been well prepared-accept as natural the guests' unanimous alignment with the intolerant Bonze. They move toward where he is standing on the stage and, following his example, "stretch out their 
THE JOURNAL OF MUSICOLOGY

EXAmple 7. Puccini, Madama Butterfly, Act 1: procession of the wedding guests, with pile-up that results in three measures sitting on an eleventh chord

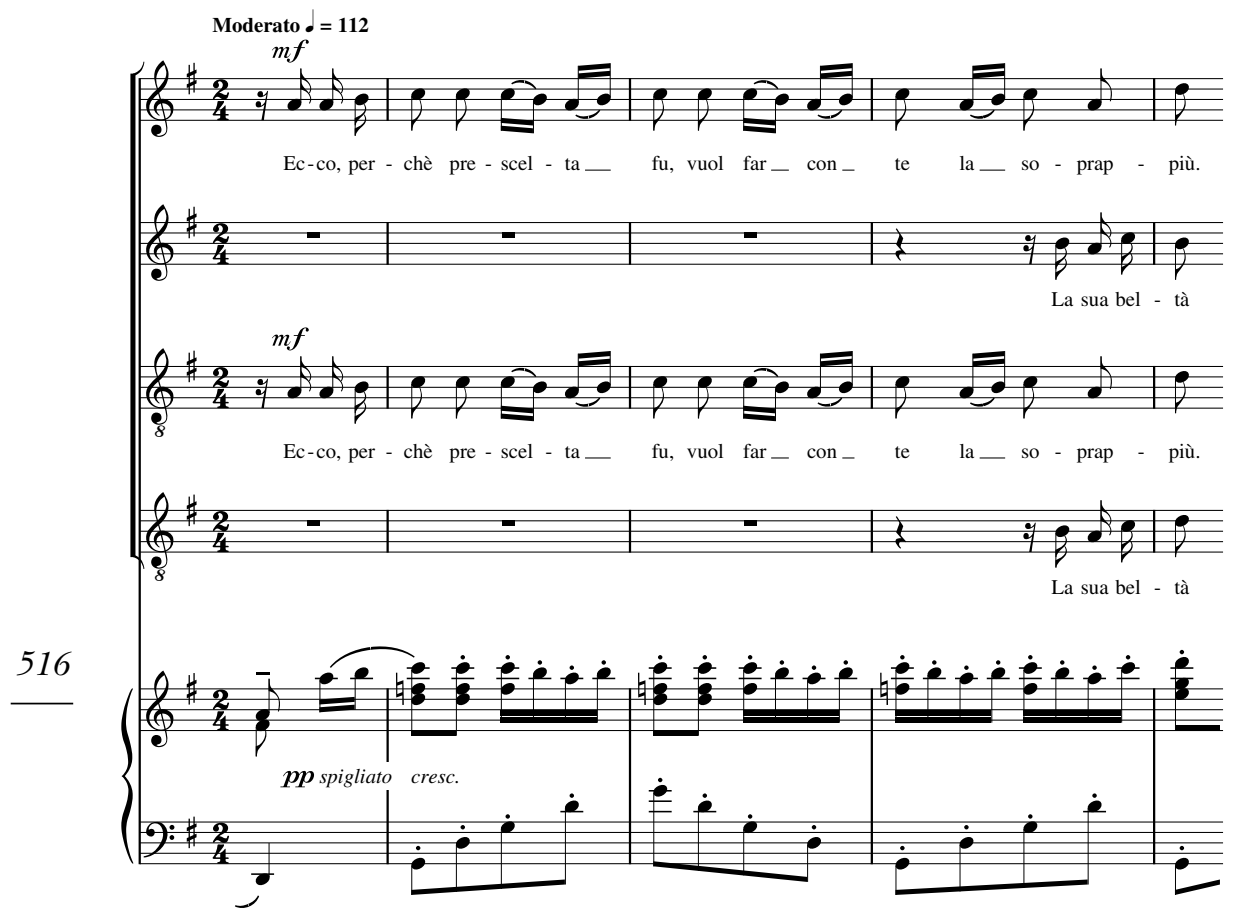

arms" and curse the 15-year-old in music whose use of the tritone is harshly dissonant-hence threatening — though not Japanese in style. 94

The last ensemble in the work is as empathetic with Cio-Cio-San and her people as the "wedding guests" ensemble was condescending. It also amounts to a ruefully realistic commentary on the imperial stance of many American soldiers, businessmen, and diplomats toward the exotic peoples-as they clearly often viewed them-whose territories they were increasingly entering and, with diverse intents, attempting to exploit.95

94 The opera's association of high dissonance and other modernist devices (including tritones and whole-tone fragments) with oppressive Japanese tradition is briefly suggested by, among others, Carner, Giacomo Puccini, 2nd ed., 386-88, 397.

95 See Narrelle Morris, "Innocence to Deviance: The Fetishisation of Japanese Women in Western Fiction, 189os-199os," Intersections: Gender, History and Culture in the Asian Context 7 (2002), accessed on May 6, 2007 at http://wwwsshe.murdoch.edu.au/ intersections/issue $7 /$ morris.html. On representations of Japan in American popular music, see the forthcoming study by W. Anthony Sheppard, Extreme Exoticism: Japan in the 
In this remarkable trio, the American consul Sharpless pleads with Cio-Cio-San's maid Suzuki to persuade Cio-Cio-San to give up her child to the "motherly care" of Pinkerton's American wife Kate in order to "safeguard the child's future." Meanwhile, Pinkerton wanders around the little house, commenting on what he is reencountering after an absence of three years: flowers, the bedroom, a statue of the Buddha, a photograph of Pinkerton himself. $9^{6}$ The three characters' words, if one merely reads them in the libretto, suggest a discussion between the baritone and mezzo, with Pinkerton muttering asides and (as the stage directions indicate) "becoming more and more agitated." Suzuki twice expresses her horror to Sharpless: "And you want me to ask a mother to. ..." (She cannot bring herself to utter the obvious last words.)

The music enacts a very different scenario, reflecting (but, I would argue, not identifying with) the power relations of imperialism. Throughout the 30 slow (largo) measures of the trio, the orchestra plays a quietly surging and ever-unfurling melody.97 Sharpless and Pinkerton take turns doubling the orchestra's melody. Beginning softly and dolce, they gradually build to an immense climax, at which the tenor holds a four-beat-long high $\mathrm{B} b$. The baritone finally joins him on his own equally intense high F. It is not Pinkerton but Suzuki who is, throughout most of the trio, reduced to muttering. Her protesting words, mostly set as recitative-like interjections, seem to bounce ineffectually off the seamless wall of male legato singing (Ex. 8).

The whole number is underpinned by a striding bass line that is often doubled by Sharpless when Pinkerton (as in most of Ex. 8) takes the main melody. Indeed, Pinkerton and Sharpless could easily perform their parts (without Suzuki) as a satisfying duet. Suzuki gives the effect of trying to get their attention while the men, focusing on their respective intense feelings, sing away..$^{8}$ Sharpless's words are, in his

American Musical Imagination. Sheppard's book will incorporate materials from two of his conference presentations: "Strains of Japonisme in Tin Pan Alley, 1900-1930" (delivered at the 2000 Society for American Music meeting) and his "Pinkerton's Lament" (delivered at the 2003 meeting of the American Musicological Society). Michaela Niccolai explores some popular songs (from Italy and America, ca. 1916-48) about Japanese women abandoned by Western males, in " 'Oh fior di thé, t'amo credi a me!': Aspetti della ricezione del mito-Butterfly nella canzone e nell'operetta fino agli anni Trenta," in Madama Butterfly: l'orientalismo di fine secolo, l'approccio pucciniano, la recezione, ed. Arthur Groos, et al. (Florence: Olschki, and Lucca: Centro studi Giacomo Puccini, forthcoming). $9^{6}$ Here and in his subsequent aria ("Addio, fiorito asil") he seems to be enacting one side of a farewell duet, rather as if Rodolfo in the end of act 2 of La Bohème set out to sing his farewell duet without Mimì.

97 This melody had been first heard when the two men arrived at the house.

$9^{8}$ A rare discussion of Suzuki stops, unfortunately, at the beginning of act 2: Melinda Boyd, "Re-Orienting' the Vision: Ethnicity and Authenticity from Suzuki to Comrade Chin," in Wisenthal, et al., Vision of the Orient, 59-71. 
THE JOURNAL OF MUSICOLOGY

example 8. Puccini, Madama Butterfly, Act 2, scene 2 trio: Pinkerton and Sharpless ignore Suzuki's concerned protestations.

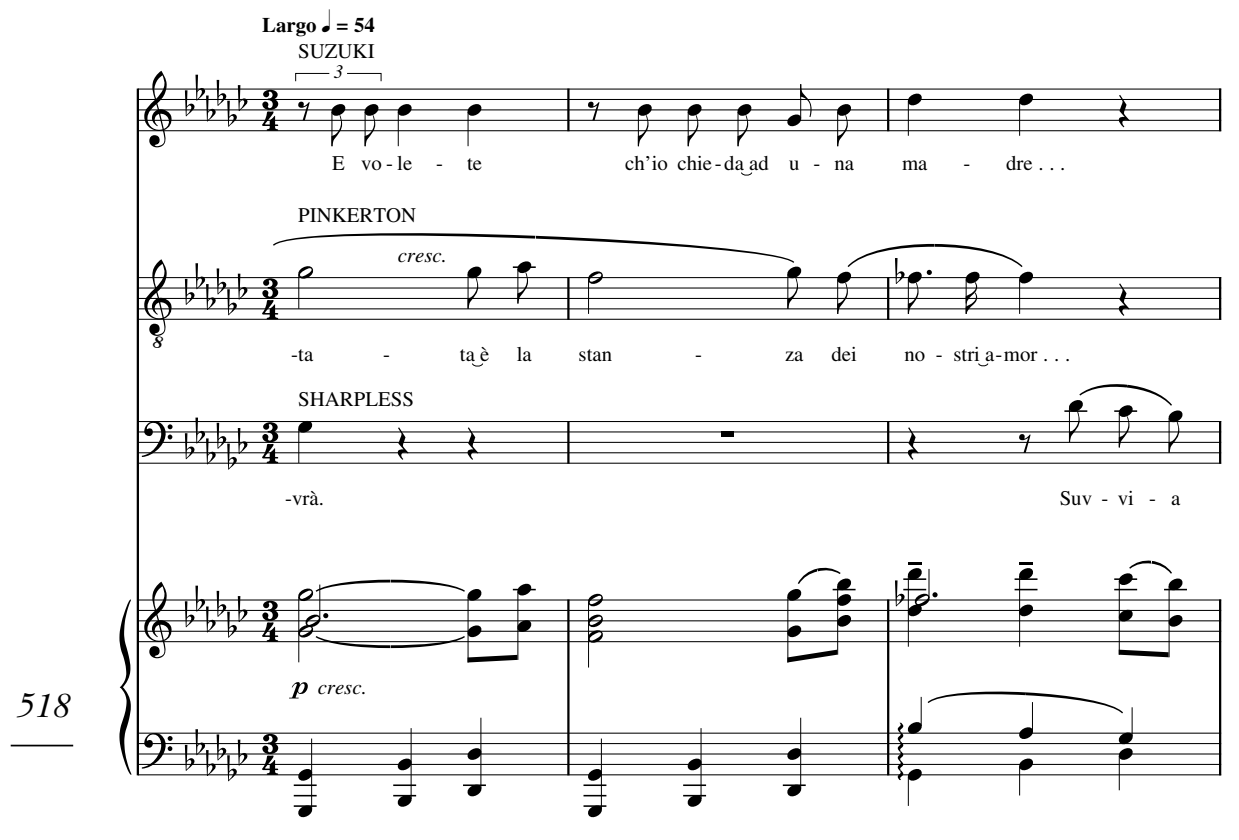

own eyes, reasonable ones, rather like those of another figure of authority, Germont père in Verdi's La traviata. But they are also-again, like Germont's-cruel, for they do not take into consideration Cio-CioSan's feelings nor anticipate that giving up her child will lead her to suicide. Pinkerton's behavior seems equally heartless. He is here taking selfish refuge in his pain, just as he has acted selfishly throughout the opera.

One imagines that the two men think their Western cultural values are superior to those of the Japanese. Pinkerton, after all, had ridiculed the Bonze in act 1 . Yet here they prove themselves to be as deaf to a Japanese woman's entreaty-as unlistening-as was the Bonze on that former occasion.

After we have experienced a performance of this trio, we may not find so implausible McClary's tentative claim that Madama Butterfly engages in a critique of imperialism and Western cultural superiority. Certainly, few listeners would endorse Mosco Carner's gripe that "this trio represents a concession on the part of the dramatist to the musicians [i.e. the composer and his singers], for the dramatic situation hardly 
warrants it."99 The stage direction at the end of this trio is eloquent: Suzuki, still resisting Sharpless's instruction that she go talk with Kate Pinkerton in the garden, has to be "thrust" (spinta) there by him. The historically determined powerlessness of the non-Western, exotic Other is vividly realized in this trio-without any exotic sounds-and in the peremptory shove from Sharpless that ends it.

$$
* * *
$$

The various musicodramatic portrayals examined above, by Rameau, Handel, Bizet, and Puccini, are quite different from those that the same composers tended to create for European characters. In particular, numerous Handel works embody the Western/non-Western dichotomy by contrasting a decadent monarch or military leader from the Middle East or India with a more principled one associated with ancient Greece or Rome or with Judaeo-Christian tradition. Typical examples, worth exploring in detail, include the contrasting pair Argante and Godefroy de Bouillon-the surly woman-chasing Muslim king versus the upstanding Crusader knight-in Rinaldo, 1711; Poro, king of India, driven by amorous jealousy, versus the more self-controlled Alexander the Great, in Poro, re dell'Indie, 1731; and our drunken friend Belshazzar versus yet another patent stand-in for the West, Cyrus of Persia (who, conveniently and in defiance of both history and the Old Testament, accepts Jehovah as Lord at the oratorio's end). ${ }^{100}$

The musicodramatic portrayals examined here have given us welcome occasion to expand our toolkit for dealing with representation of the exotic Other, allowing us to consider the whole range of musical styles and procedures, as well as verbal, dramatic, and other features. The same is surely true of thousands more such exotic works: first-class ones and ones that are (as we say when all else fails) historically interesting.

99 Carner, Puccini, 397. Carner goes on to object that Pinkerton's fortissimo high Bflat would have woken Butterfly; Carner seems to have forgotten, for the sake of a condescending joke, that moments of internal monologue in opera are often sung loudly, and understood by us as not being audible to other characters in the vicinity. Puccini and the librettists play with this convention in Act 1: Butterfly's lengthy confession of love ("Ieri son salita") is sung in an extended aside to Pinkerton, but her final notes are forte and she then "stops, as if afraid to have been overheard by her relatives."

100 On characterization in Poro, see the insightful pages in Winton Dean, Handel's Operas, I726-I 74I (Woodbridge, UK: Boydell Press, 2006), 169-85. But Dean reverts to the usual Exotic-Style Paradigm in his one sentence about the possible occurrence of exoticism in the work: "Four of the six characters are Indians, but there is no attempt at local color" (ibid., 184). "Local color," for Dean here, seems not to include Poro's extreme emotional traits, so brilliantly realized in Handel's music, nor the scene near the end in which Cleofide, thinking Poro dead, prepares to commit sati (suttee) on an onstage funeral pyre. Metastasio's libretto, originally entitled Alessandro nell'Indie, was based in large part on Racine's play Alexandre le Grand (1665). It served as the basis for some 65 operas in the course of the 18 th century, including no fewer than five between January 1730 and January 1731 (ibid., 172). 
THE JOURNAL OF MUSICOLOGY

By broadening our approach, we move away from a narrow (if often productive) search for necessary-and-sufficient musical signifiers, embodied in the pitches, rhythms, and instrumental colors of the score alone. Instead, we recognize how extensively music has participated, for centuries now, in what literary critics and cultural historians call the "representation" of the non-Western world and of other peoples on the margins of metropolitan consciousness. Participated, that is, by engaging all of music's possible tools-such as state-of-the-art harmonic language and imaginative manipulation of phrase structure-and by allying itself with other arts: sung words (or movement titles in certain instrumental pieces), dramatic action, dance, and so on.

Numerous scholars and commentators writing on specific operasnot just the few mentioned here-have anticipated some aspects of the "All the Music in Full Context" Paradigm. But none of them, to my knowledge, has stated her or his working principles explicitly, systematically, or (in a sense) theoretically. We need to link those studies of individual works to each other, consider their various implications, carry out their arguments in greater detail, and test them against yet other instances of exotic portrayal per musica whose ways of representing the exotic have hardly been examined at all.

Eastman School of Music University of Rochester

\begin{abstract}
Most previous writings on musical exoticism reflect the unspoken assumption that a work is perceived by the listener as exotic only if it incorporates distinctively foreign or otherwise highly unusual elements of musical style. This "Exotic Style Only" Paradigm often proves revelatory, especially for purely instrumental works. In operas and other musicodramatic works set in exotic locales, by contrast, music is heard within a narrative "frame" that shapes the listener's response. Yet the existing literature on "the exotic in music" tends to restrict its attention to those few scenes or passages (in such works) that "sound non-Western." It also tends to leave unmentioned the many Baroque-era operas and dramatic oratorios that focus on despicable Eastern tyrants.

The present article proposes an "All the Music in Full Context" Paradigm to help make sense of a variety of exotic portrayals that are strikingly diverse in message and means: 1) Les Indes galantes (Rameau's application of standard musico-rhetorical devices to manipulative and anti-colonialist speeches by the Peruvian leader Huascar); 2) Belshazzar (Handel's vivid musical setting of the passage in which the cruel, cowardly Eastern despot seeks oblivion in drink); 3) Bizet's Carmen (the
\end{abstract}


Card Scene, which is notably free of Hispanic or other local color yet, through rigidly recurring devices in voice and orchestra, indelibly limns Carmen's Gypsy fatalism); and 4) three prominent dramatic moments, two of them rarely discussed, in Puccini's Madama Butterfly. In each case, the full range of artistic components-including musical devices that lie within or outside the traditional exotic vocabulary-enriches our understanding of how diversely, powerfully, sometimes disturbingly the exoticizing process can function in genres that combine music with dramatic representation.

Keywords:

Carmen (Bizet)

Belshazzar (Handel)

exoticism

Les Indes galantes (Rameau)

Madama Butterfly (Puccini) 